\title{
実験的咬合異常がラット下顎頭に及ぼす影響に関する 病理組織学的及び走查電子顕微鏡的研究
}

\author{
九州歯科大学大学院歯学研究科口腔外科学第 1 専攻（指導：山田長敬教授） \\ 枌 浩 一 \\ 昭和59年12月 6 日受付
}

Histopathological and Scanning Electron Microscopic Studies of the
Mandibular Condyle Following Bilateral Loss of Occlusion in the Rat Kouichi Hegi

First Department of Oral Surgery (Director: Prof. Nagayoshi Yamada) Kyushu Dental College, Kitakyushu, Japan

There are various studies in which malocclusion was experimentally induced and its influence on the temporomandibular joint was histopathologically examined. The mandibular condyle, especially the cartilaginous layer undergoes main changes, which are greatly varied and on which there has been no uniform view yet. Therefore, in order to make a more minute examination of the influence of malocclusion on the temporomandibular joint, malocclusion was experimentally induced in rats by upper, right and left, total molar extraction (A group, forty animals) and by periodic grinding of upper, right and left incisors plus the foregoing total extraction (B group, forty animals), and histopathological and scanning electron microscopic examinations were made of the changes in the mandibular condyle.

The results were as follows:

1. Both experimental A and B groups showed the same weight gain tendency as control group.

2. Specific changes were observed early at the embryonic zone ranging from the central to internal area in experimental A group.

a. Light microscopic observations revealed that from the first post-operative week, cells in the area adjacent to the articular zone presented roundness. These cells covered the entire embryonic zone at the sixth week, and thereafter the cellular arrangement became irregular with an increase in cartilage matrix.

b. SEM observations revealed that from the first post-operative week, cells near the articular zone presented many processes, which continued to grow up remarkably up to the second week, and the cells presented roundness morphologically. Thereafter these processes decreased and from the ninth week the collagenous fibrils of the matrix traveled irregularly in part. 
3. Greater specific changes were observed early at the embryonic zone of the internal area in experimental B group than in experimental A group.

a. Light microscopic observations revealed that the cartilage matrix increased by the week, and that cellular morphology presented roundness and cellular arrangement became irregular to the most remarkable extent at the fourth week. Thereafter cellular arrangement became a little regular, but cellular morphology presented more roundness and was no longer distinguishable from the transitional zone.

b. SEM observations revealed that changes of the collagenous fibrils of the matrix began as their disturbed traveling, leading to their small fasciculation to the most remarkable extent at the fourth week. Thereafter their traveling became regular and showed a tendency toward compactification.

4. The cartilaginous layer of the mandibular condyle was already thin, especially at the hypertrophic zone, at the third post-operative day in both experimental A and B groups. However, by the third week the layer became hypertrophic inversely, and from the fourth week it was re-thinned.

5. In neither $A$ nor $B$ group any great change was observed at the external area of the mandibular condyle.

6. Bone resorption of the lateral pterygoid attached bone margin of the mandibular internal neck stopped almost completely at the ninth week in control group, while in experimental groups there still remained bone resorption picture even then.

7. Ossification of the mandibular condyle proceeded in the order of control group, experimental A group, and experimental B group.

The above results suggested that difference in malocclusion was correlated with the extent of abnormality of the temporomandibular joint.

Key words: Malocclusion/Tooth extraction/Scanning electron microscopy/ Mandibular condyle

\section{緒 霉}

日常歯科臨床に扔いて，顎関節の異常を訴えて来院す る患者が年々増加している.しかしながら，診断並びに 治療法にいまだ統一した見解は確立されていないのが現 状である。そこで荬学各分野において，それぞれの立場 から多くの研究がなされてきた。その結果，咬合異常が 重要な病因の 1 つとして注目されるに至っている1ー11.

従来より，咬合異常を実験的に惹起し，顎関節への影 響を検索した研究は種々みられる12-14)。なかでも歯 牙欠損に上る顎関節への影響汇関する実験的研究は，

Avant $ら(1952)^{15)}$, Cimasoni (1963) ${ }^{16}$ ', Furstman $(1965)^{17}$, 小野ら $(1967)^{181}$, 檜山 $(1968)^{191}$, 鈴木 $(1971)^{201}$, 河野 $(1977)^{211}$ ，角野 $(1983)^{221}$ らがラ
ットやイヌを使い，また本教室の喜久田 $(1980)^{23)}$, 樋 日 $(1982)^{24}$ はサルを使い，いずれも病理組織学的に検 索を行なっている．そして，その主要な変化が下顎頭， 特に軟骨層に現れることでは一致しているが，その変化 は多様性に富み，いまだ統一した見解はなく，不明な点 が多い.

最近, 顎関節の微細構造究明のために, 電子頙微鏡を 使用した報告がみられるようになり，塩田ら $(1980)^{25}$ はラットの下顎頭を, 田口 $(1980)^{26)}$ はラット, イヌ, サルの下顎頭と円板を走査型電子顕微鏡 (SEM) で， また Silbermann ら $(1974)^{27}$ はマウスの下顎頭の成 長軟骨を，塩田ら $(1980)^{28)}$ ，森田 (1982) ${ }^{29}$ らはラッ

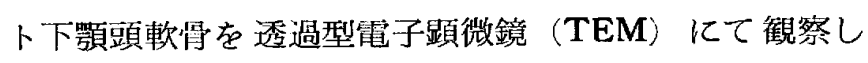
ている. そして下䫟頭の正常微紐構造が徐々に解明され 
つつあるというのが本分野の現状である。

しかしながら, 咬合翼常時における顎関節の微細構造 を観察したものは極めて少なく，价施ら（1976，1978） 30，31)がラットで椈牙欠損を作り，またカニクイザルで 補緅物による咬頭干渉を作成し，SEM で観察したもの のみで，その内㝘も概要を述べているに過ぎず，詳紐さ に欠けているように思われる。

そこで実験的に咬合異常を惹起させ，顎関節への影響 を電子顕微鏡にて観察し，さらに微紐に検索することは 顎関節異常と咬合異常との関係を解明する上で意義ある ことと考える。

著者は実験動物として広く使われるラットを用い，咬 合異常に対する下顥頭の変化を，さらに詳組に検案する

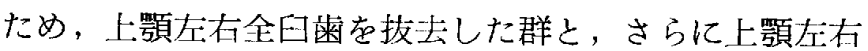
切崡の削合を併せて行なった群との下顎頭, 特に軟骨層 を病理組織学的及び走査電子顕微鏡的に検索を行い，い ささかの知見を得たので報告する。

\section{実験動物ならびに実験方法}

\section{I．実験動物}

奏験には生後60日（体重 $260 \pm 20 \mathrm{~g}$ ）のWistar 系雄 ラット96匹を使用した。なお，全動物とも恒温，恒湿の 飼育室にて，アルミケージに一䦻づつ入れ飼育した。飼 料はオリエンタル社製固型徐料 $(\mathbf{F M})$ を, 飲料水は水 道水を常時与え，可及的に同一条件下で飼育した。

\section{II . 実験方法}

実験動物を次の3 群に分けた。

1) 対照群（16匹）；無処置

2）奏験A群（40匹）；上顎左在全四菌存抜上

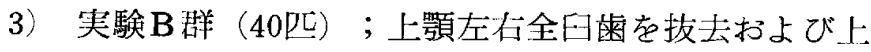
㖽左右切歯を歯間乳頭部まで毎週削合

観察経日は施術後，3 日，1 週，2 週，3 週，4週，

6 週, 9 週, 15週とし, 各経日に対照群 2 㶤, 実験群各 々 5 匹とした。

すべてのラットは各経日ごとに体重を測定した．

試料採取はまずネンブタール $(0.5 \mathrm{ml} / \mathrm{kg})$ 腹腔内注 射による麻酔後, 右下顎頭を摘出し SEM 用整本とし, その後, 薬量を増して薬殺, 断頭し左下顎頭を光顕用畋 本とした。

\section{III. 試料作製法}

\section{A . 光顕標本}

断頭後，10\%中性ホルマリン液にて固定した。固定 後, $5 \%$ 硝酸液にて脱兏, 通法に徒いパラフィン包埋 し， $6 \mu \mathrm{m}$ の前額断連続切片標本を作製した．その標本
をへマトキシリン・エオジ重染色にて鏡見した。

B. SEM 標本

摘出した試料を Karnovsky の液 $\left(4^{\circ} \mathrm{C}\right.$ ， phosphate buffer pH 7.4) で固定した. 固定後,トリミングを行 ない, アルコール系列にて脱水し, 液体窝素で凍結し, 下顎頭を前額方向にアルコール凍結割断を行なった。制 断後，再びアルコール系列にて，蒸留水にもどしたの ち,タンニン・オスミウム法で導電染色を施し, 再度アル コール系列にて脱水，酢酸イソアミルに置換，液体炭陵 ガスによる臨界点乾燥（日立，HCP -2 型)を行なった。 割断酒には $\mathrm{Au}-\mathrm{Pd}$ イオンコーティング $(\mathrm{JFC}-1100)$ を行ない，JSM－25型走查電子顕微鏡にて観察した.

\section{実 験 成 績}

\section{I. 体重変化}

対照群と実娩A群，B群の体重変化は図に示す（図 1).

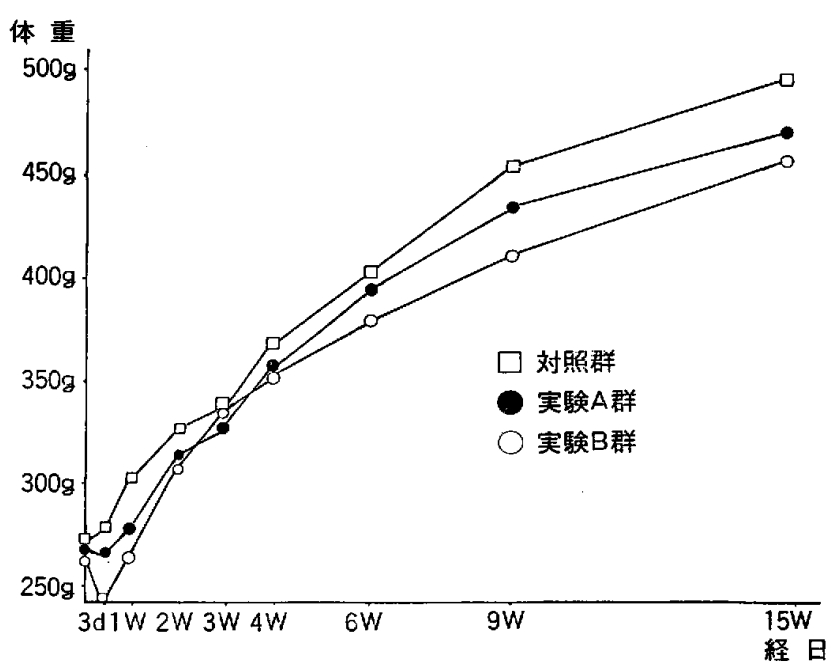

闵 1 体重変化

実験群では実験後 3 日目までわずかな体重の減少が認 められ，実験 $\mathrm{A}$ 群で平均 $7 \mathrm{~g}$, 実験 B群では平均 $14 \mathrm{~g}$ 減 少している. それ以後は徐々に増加しはじめ， 1 週目に おいて，実験 $\mathbf{A}$ 群では実験前よりも増加し，実験B群で も実験前と同じまで回復している．3 週目になると対照 群，実験A群，B群ともほとんど差はなくなっている。 以後，同しような增加傾向を示す。

II. 対照群組織所見

A . 光顕所晃

下顎頭軟骨層を次の 5 層に分類した。最表層 articular zone は, 線維成分がほとんどでへマトキシリンに 濃染する扁平な細胞が散在する．第 2 層は embryonic zone で，ヘマトキシリンに濃染する楕円状の核を有す 
る扁平な細胞が，その長軸を下䫁頭表面に平行かつ密 に規則正しく並んでいる．第 3 㬝は transitional zone で，細胞質に富み，形態は類円形を吴し， embryonic zone に較べて軟骨基質の増加が認められ，細胞の配列 はわずかに疎になっている、第 4 序は hypertrophic zone で，細胞は肥大し，核の空胞化をきたした細胞が 多数みられる。第 5 層は erosion zoneで, 変性した軟 骨細胞が調囲の不灰化した基質にとり込まれ，骨梁形成 の母体となっている．さらに墚層では，乙の骨梁が骨化 する.

対照群 3 日目所見では，下顎頭軟骨層は中央部で愿 く,内外雨側とも薄くなって扔り三日月状を呈している. 各層の厚さは, articular zone, embryonic zone では 外側から内側の全体にわたり愿さは一定である．transitional zone は, 中央部においては $5 \sim 6$ 層より構成 されるが，内外雨側へ移行するにつれて薄くなってい る. hypertrophic zone は最も厚く, 中央部で $8 \sim 10$ 層よりなり，側方で薄くなっているが，内側に較べて处 側でより薄くなっている（写真 $1 ， 2 ， 3$ ）。

また，内側頸部における外側翼突筋付着部の骨縁に骨 吸収が諗められ，迎縁は鋸歯状を呈している。

対照群の経日的変化として，4週目までは特に大き な変化はなく，下顎頭軟骨層において，hypertrophic zone がわずかに薄くなっており，その下方の骨梁は軽 度に太くなっている，また，内側頸部の外側翼突筋付着 部骨緣の骨吸収は軽減するも，いぜん鋸歯状を呈してい る。

9 週目では下顎頭軟骨層において, embryonic zone の細胞の形態に変化はみられないが, 細胞数は減少し, 配列は疎になっている。また，乙の層の厚さもやや薄く なっている. transitional zone の厚さは中央部で 1 〜

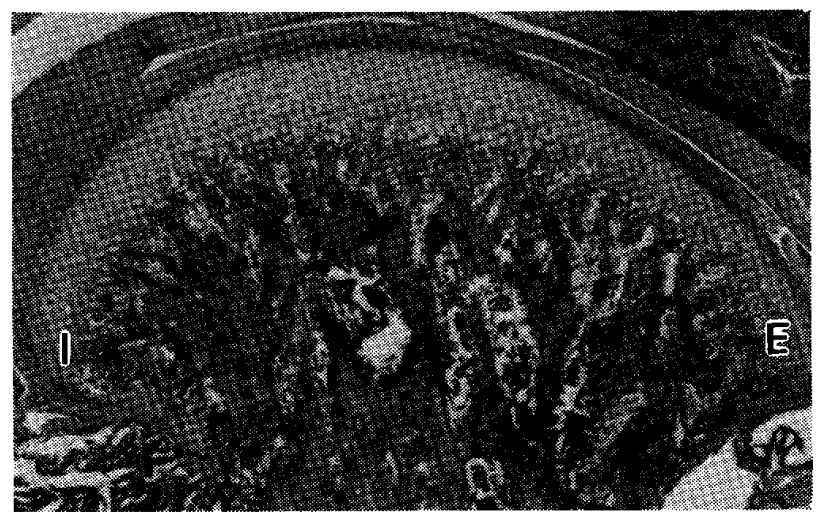

写真 1 対照群 3 日目所見 $(\times 40)$

$$
\text { I -内側 } \mathrm{E} \text {-多側 }
$$

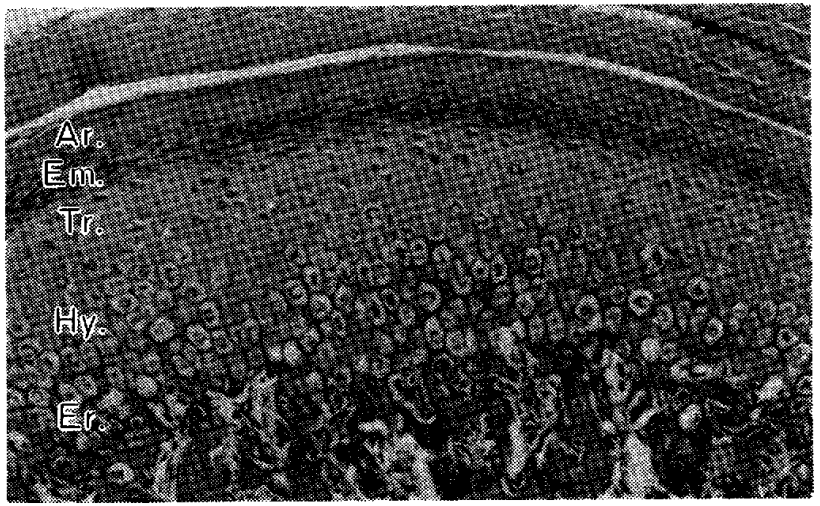

写真 2 対照群 3 日目所見 $(\times 100)$ 中央部軟骨層
Ar. Articular zone
Em. Embryonic zone
Tr. Transitional zone
Hy. Hypertrophic zone
Er. Erosion zone

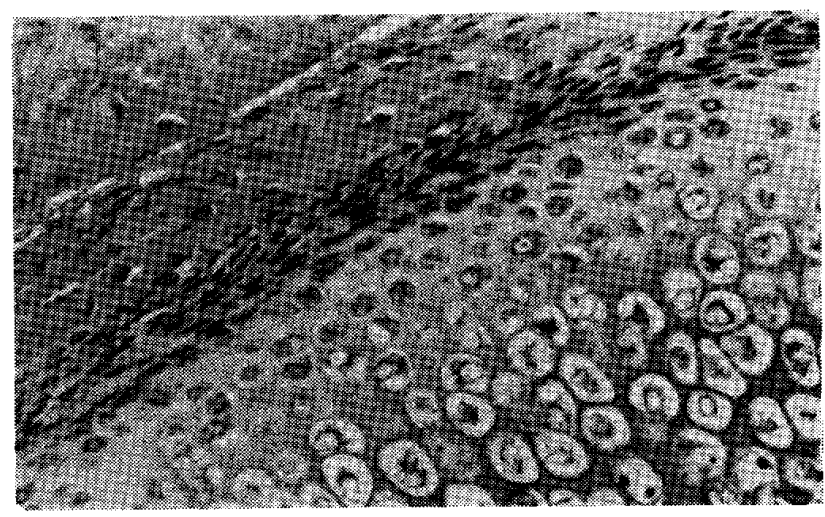

写真 3 対照群 3 日目所胃 $(\times 200)$ 中央部内側軟骨層

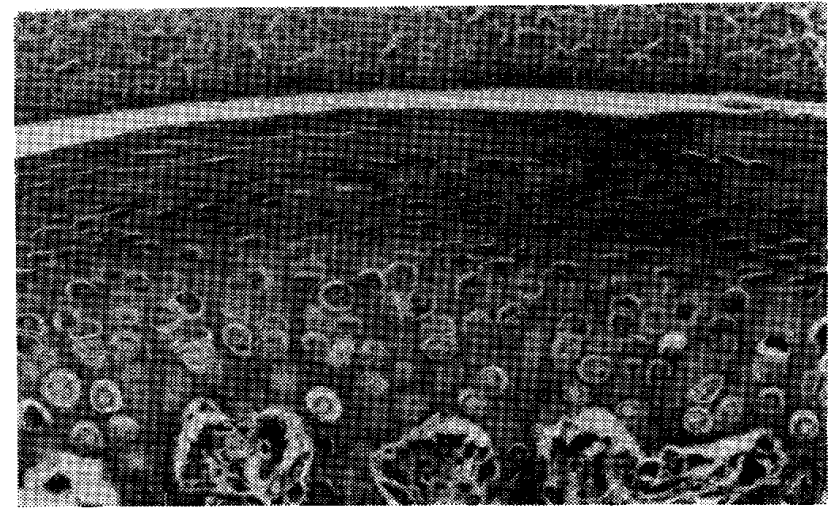

写真 4 対照群 9 週目所見 $(\times 200)$ 中央部軟骨層

2 層, hypertrophic zone は $2 \sim 4$ 層と非常に薄くな っている。このため軟骨層は非常に菲溥化している（写 
真 4 ).

また，骨梁はさらに太さを増し，骨化が進み，骨髄腔 は狄袏し，下顎頭は骨質の占める割合が增大する。

内側頸部の外側翼突筋付着部骨縁の骨吸収所見はほ之 んど消失し，骨縁は比較的平坦である(写真 5 ).

15週目の下顎頭軟䯚層は 9 週目と闰様な所見を声して いる，骨梁の骨化はさらに進み，下顎頭は骨質の占める 劃合がさらに増大する(军真 6 ).

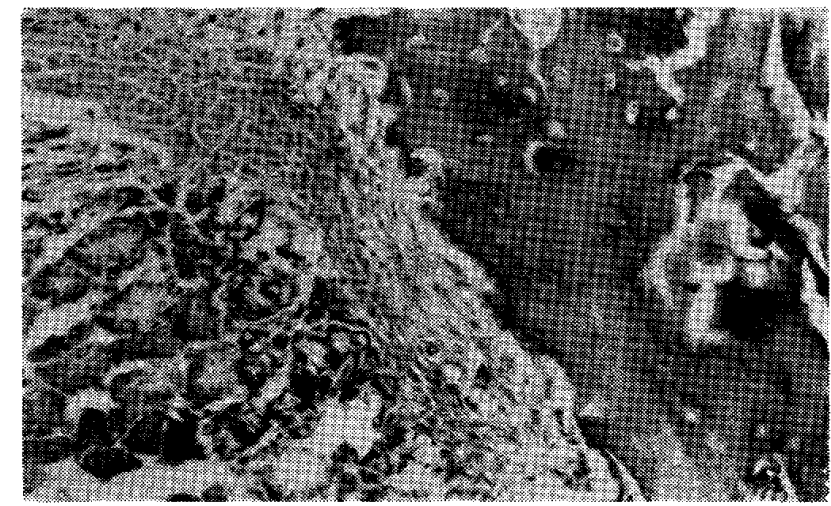

写真 5 対照群 9 週目所見 $(\times 200)$

内側頸部の外側翼突筋

付着部骨緣

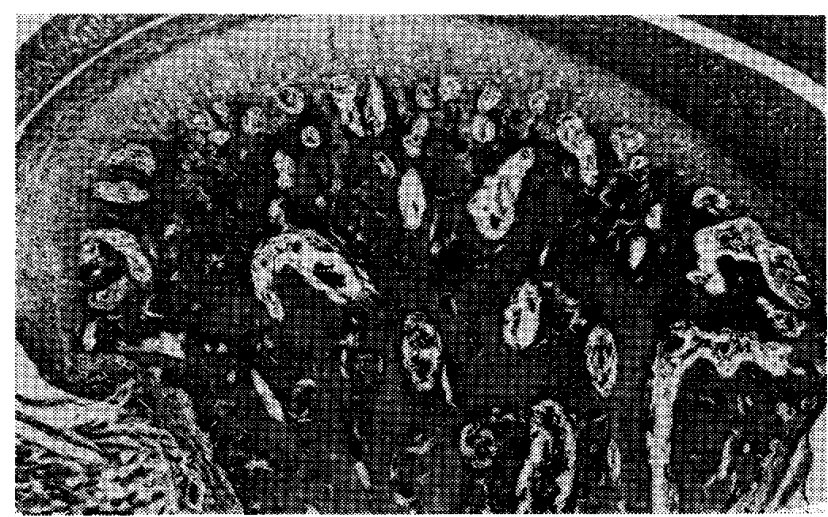

写真 6 対照群 15 週目所見 $(\times 40)$

\section{B . SEM 所㫕}

下顎頭軟骨層は灮顕所見と同じように5 首に分類でき る.表層の articular zone は線維網として観察され， 下顎頭表面には西行に走行し，前後方问，内外方向には 不規則に走行している. embryonic zone の細胞は長さ $5 \sim 7 \mu \mathrm{m}$, 幅 $2 \sim 3 \mu \mathrm{m}$ の細長い細胞で, 長軸存下額 頭表湎に対して平行に規則的に密に配列している.ま た，紐胞と紐胞小腔との間に空䊗はなく，周囲の基質の 膠原原線維は直径 $100 \sim 160 \mathrm{~nm}$ の太さで前後方向に豊富 に走行している. transitional zone の細胞は直径 $7 \sim$
$10 \mu \mathrm{m}$ の類円形を是しており，細胞小腔との間に空腺は 認められない，また，配列は embryonic zone より疎 になっている. hypertrophic zone の紐胞はさらに大 きく, 直径 $10 \sim 13 \mu \mathrm{m}$ の類円形を是し, 細胞小腔との間 に空陌が認められる(写真 7，8，9）。

III. 実験A群の組織所見
A . 光顕所見

3 日目

下顎頭軟骨首は内外両側において, 対照群と較べて特 に変化は認められないが，中央部において hypertro-

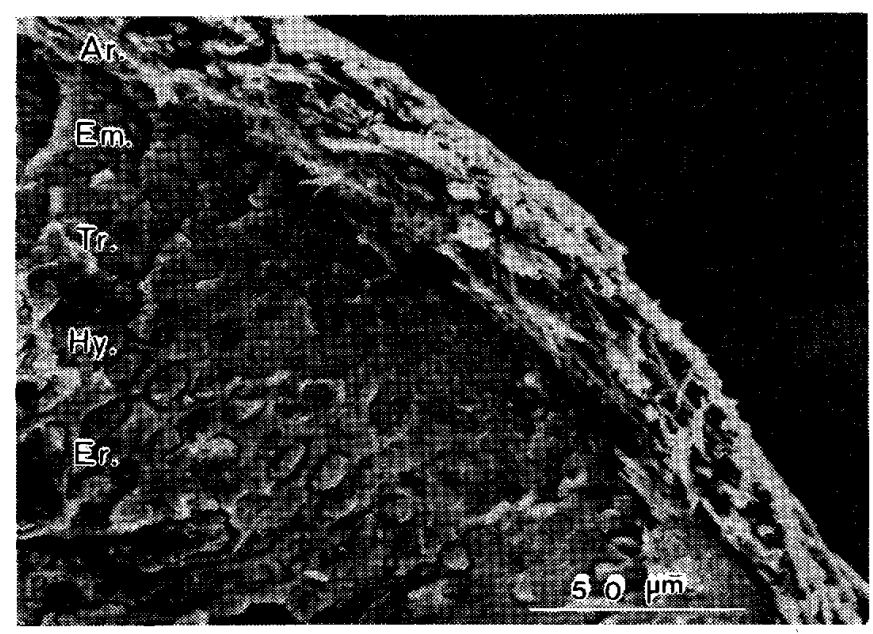

写真 7 対照群 SEM 所見 中央部内側軟骨層

Ar. Articular zone

Em. Embryonic zone

Tr. Transitional zone

Hy. Hypertrophic zone

Er. Erosion zone

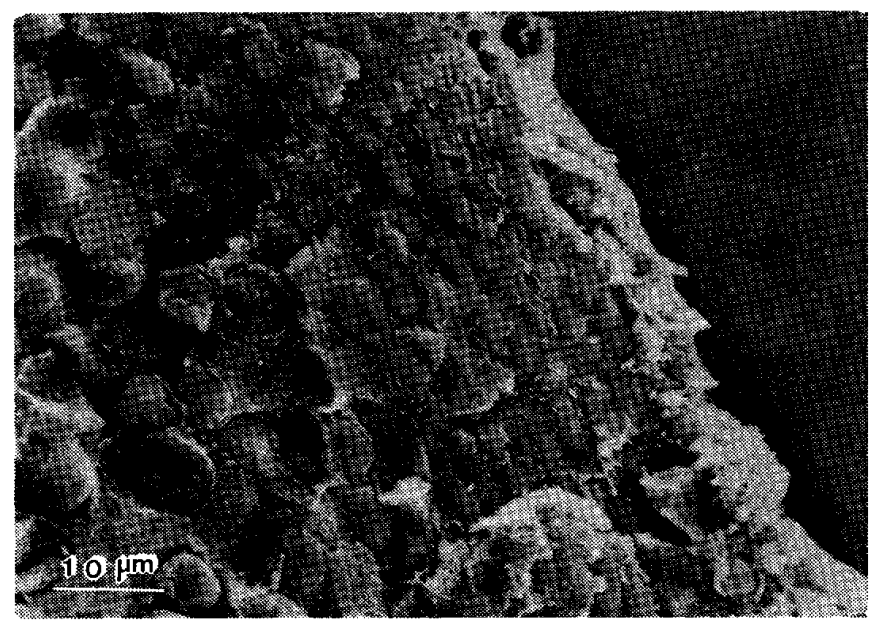

写真 8 対照群 SEM 所昌 内側部軟骨層 


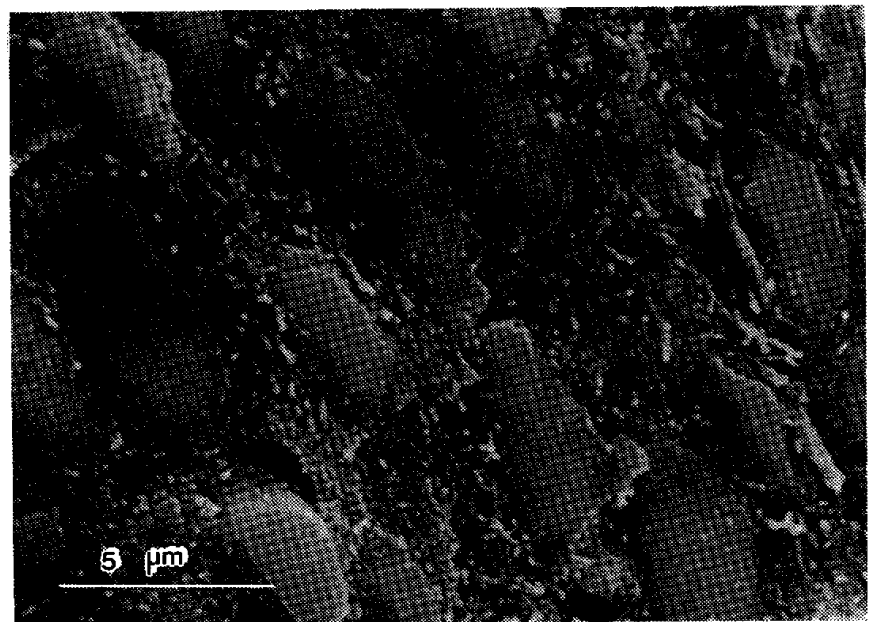

写真 9 対照群 SEM 所見 内側部 Embryonic zone

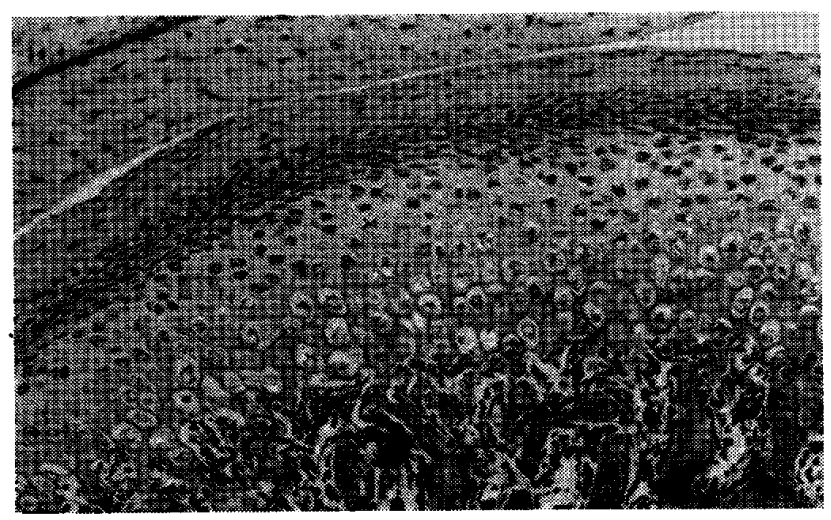

写真10 実験 $A$ 群 3 日目所見 $(\times 100)$

phic zone の厚さは対照群のほぼ半分の厚さで $4 \sim 5$ 層 しか認められない（写真10）しかし，細胞の形態や配 列には特に変化はみられない，その上方の articular zone, embryonic zone, transitional zone は規則的 な配列をしており，細胞形態や層の厚さにおいても対照 群と差異はない。

骨梁は対照群と同じように，下顎頭表面に垂直方向に 規則的に走行している.

内側莖部の外側翼乫筋付着部の骨縁に骨吸収が認めら れるが対照群と差異はない。

\section{1 週目}

下須頭軟骨層外側において, 対照群と較べて特に変 化は認められない，中央から内側にかけての articular zone に接する embryonic zone にやや丸みを帯びた 細胞が $2 \sim 3$ 層認められ，その配列はやや不規則でかつ 疎である(写真11). transitional zone には特に変化は 認められない. hypertrophic zone の府さは 3 日目よ りもさらに薄くなっており，その下方の骨梁の走行に一。

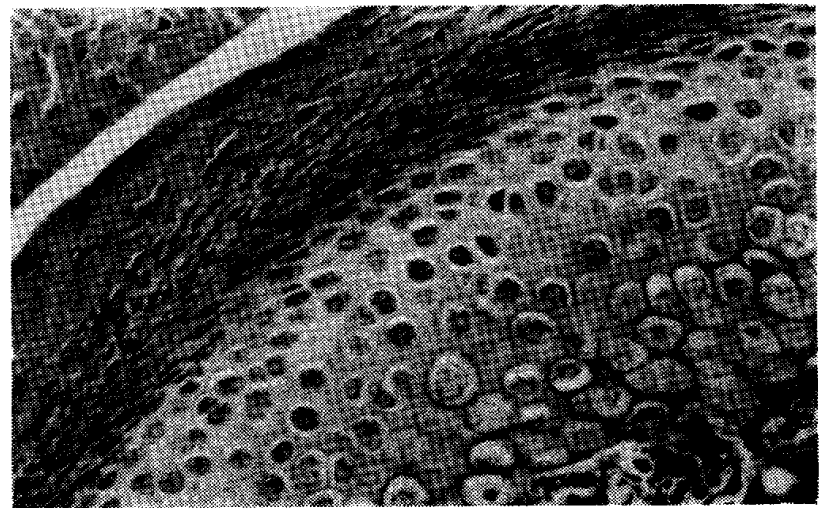

写真11 実験A群 1 週目所見 $(\times 200)$

部不規則になった所が証められる。

内側顠部の外側翼突筋付着部骨縁の骨吸収は対照群と 特に差異は認められない。

2 週目

下顎頭軟骨層外側に扔いて，対照群と特に変化は認め られない，中央から内側にかけての articular zone に 接する embryonic zone の丸みを帯びた 緗胞は 1 週目 と特に形態的な変化は認められず， $2 \sim 3$ 圈よりなり配 列は不規則でかつ疎である. transitional zone は 1 週 目に較べて軟骨基質の増加が認められ，厚さも6〜8 層 と対照群よりも厚くなっている．紐胞の形態においては 特に変化は認められないが, 配列はわずかに疎になって いる. hypertrophic zone の厚さは 1 週目よりも愿く なってはいるが, 対照群よりはまだ薄く, 細胞の形態も やや膨化したものが認められ，細胞の大きさが大小不同 になっている。

その下部の骨梁の走行は 1 週目よりも規則的で，下罘 頭表面に対し垂直的に走行している.

\section{3 週目}

下買頭軟骨首において，中央から内側にかけての articular zone に接する embryonic zone の丸みを帯び た細胞は 2 週目より細胞数の堌加が喼められ，中央部内 側よりでは擪さがわずかに厚くなっている。またてての ような細胞の認められる範囲が中央部, 内側部両方に扰 大している. transitional zone は 2 週目上りも浦くな っているが，対照群とは差が認められない，hypertrophic zone の細胞の大きさは 2 週月よりも規則的であ り，居の厚さはさらに原くなっている（写真12）。

下顎頡中心部の骨梁はさらに太さを增し，骨髄腔は狄 寉し，下頟頭全体に占める肖質の割合が多くなってい る

4 週目 


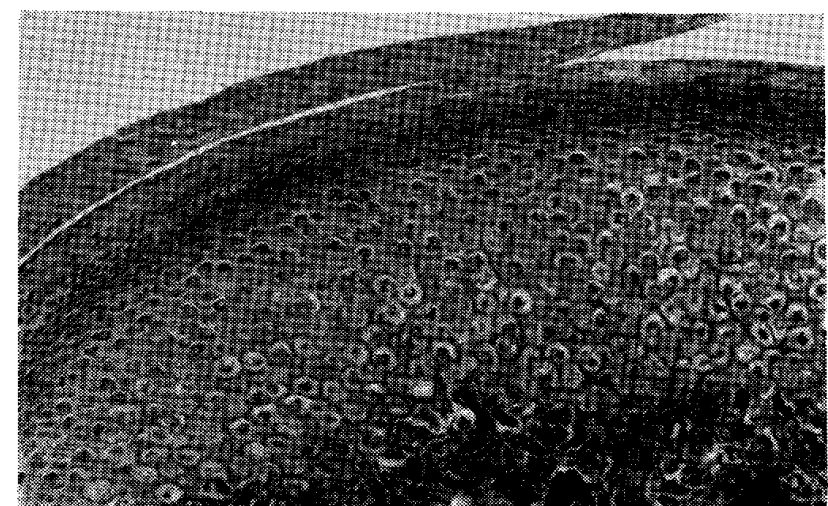

写真12 実験A群 3 週目所見 $(\times 100)$

下顎頭軟骨層の菲溥化が進んで扔り，外側においても hypertrophic zone が対照群に較心゙てわずかながら薄 くなっている.しかし，細胞の形態や配列には対照群と 差異がみられない。护から内側にかけての articular zone に接する embryonic zone において，丸みを帯 びた細胞間を占める軟骨基質が著明に増加し，このた め, embryonic zone 表層を占める細胞層が厚くなっ ている.その唇みは transitional zoneよりに存在する 屏平な細胞の層と同しくらいになった所む患められる。 また，䛿平な細胞間の軟骨基質もわずかに増加した所が 認められる (写真13). hypertrophic zone の厚さは 3

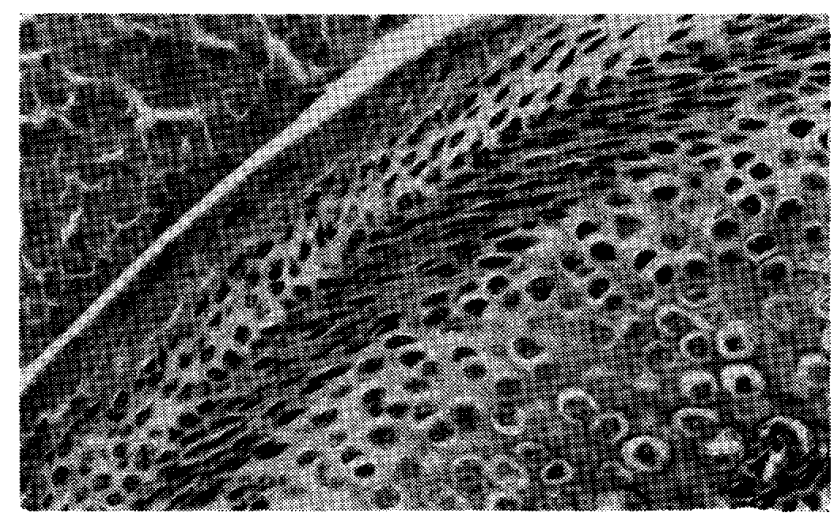

写真13 実験 $\mathrm{A}$ 群 4 週目所見 $(\times 200)$

週目に較べて薄くなっており対照群の $/ 3 / 3$ 程度である。

肖梁は太くなっており，特に内側に移行するに徒って

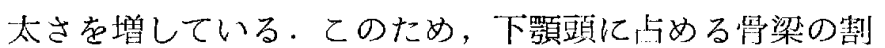
合はさらに増加している。

6 週日

下顎頭軟骨層外側において，4 週目と同様にわずかに 菲薄化している.内側では embryonic zone の棈円状 の核を有する扁平な細胞が消失し，かわって丸みを帯び 染色性がわずかに低い，配列も不規則な紏胞でおきかえ

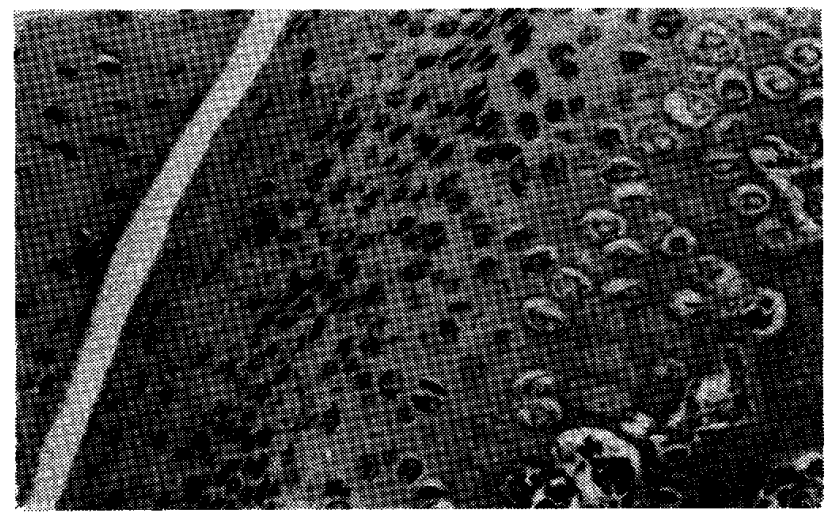

写真14 実験 $\mathrm{A}$ 群 6 週目所見 $(\times 200)$

られている。そのため transitional zone の細胞と似て おり，境界が不明瞭になっている（写真14）．その中央 よりの articular zone では線維の走行が一部乱れ, 線 維束に離開, 蛇行が認められる.

管梁の形成はさらに進み，骨膸腔は㹨窄している。

内側頸部の外側翼㔖筋付着部骨縁の骨叹収は軽度にな っているが，吸収窩はいぜん鋸曾状を呈している。

\section{9 週目}

下顎頭軟罥層は中央より内側にかけての embryonic zone で軟骨基質の增加が琹められ，細胞の配列は踈で， かつ不規則である．細胞の形態はやや丸みを帯び大小不 同で，陑平な細胞が消失した所も認められる。また，同 部の transitional zone との境界は不明瞭であり, transitional zone 6軟骨基質の増加が認められ，細胞の 配列も不規則になっている. 中央部内側よりの articular zone の線維束の離開, 蛇行は 6 週目よりも強く認 められる(写真15).

内側頸部の置吸収像は減少しているが，哃縁はいぜん 鋸歯状を呈している（写真16）。

15週目

下顎頭軟骨读外側において， hypertrophic zone の

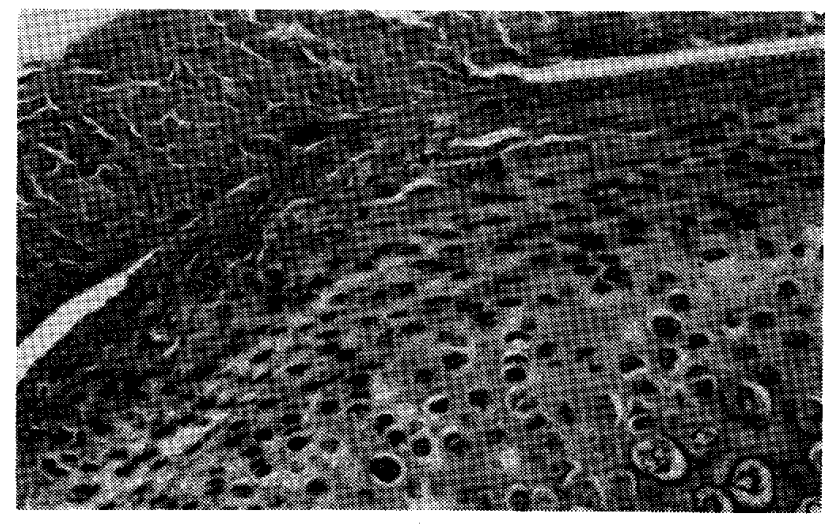

写真15 実験A群 9 週目所見 $(\times 200)$ 


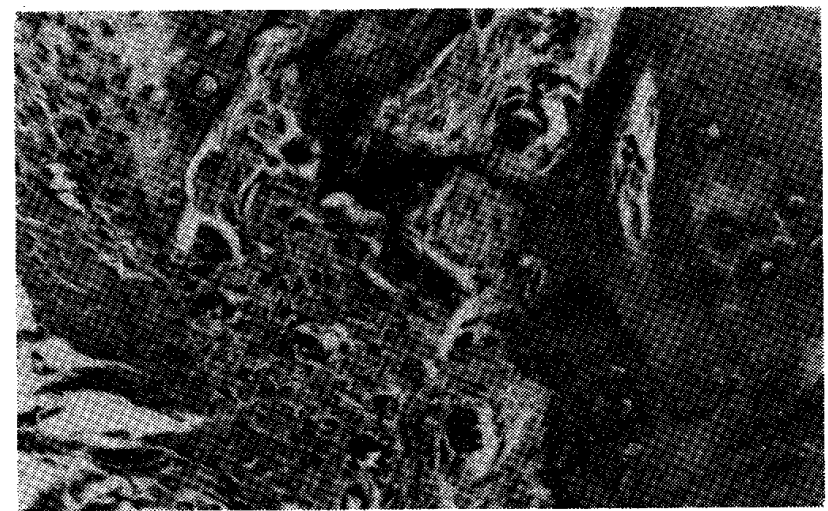

写真16 奏験A群 9 週目所見 $(\times 200)$

内側頸部の外側翼突筋

付着部骨縁

厚さが対照群より薄くなっている。しかしながら，外側 における他の層においては対照群と差異はない，6週， 9 週目でみられた中央部内側よりの articular zone の 線維束の離開, 蛇行の所見は消失し, 対照群と差を認め ない. 中央から内側にかけての embryonic zone の軟 骨基質は 9 週目よりさらに増加し, 細胞の形態はより丸 みを帯び，細胞数は減少し，配列は不規則で聶になって いる.とのため transitional zone との境界がさらに不 明膫である(写真17). hypertrophic zone は 9 週目よ り薄くなっており 2 首しか認められない。

下顎頭の骨化はさらに進み，対照群よりも著明で，内 側はほとんど骨質でしめられ緻密高化が著明である(写 真18).

内側頸部において, 外側翼突筋付着部骨縁の骨吸収所 見は認められず，骨縁は平坦になっている。

\section{B. SEM 所見}

\section{3 日目}

中央部内側の embryonic zone の細胞の形態は対照 群と較べわずかに細胞質突起の発達がみられ，幅がやや 短かく細長い形態のものが多くなっている.しかし配列 はいぜん規則的で密である. transitional zone の細胞 は直径 $7 \sim 10 \mu \mathrm{m}$ で類円形を呈し対照群と差異は認めら れない。

\section{1 週目}

中块部内側 $の$ articular zone よりの embryonic zone の細胞は細胞躓哭起が発達し, 形態は不定形を呈 している. 細胞の配列は規則的であるが，刘照群よりも 疎になっている. また transitional zone よりの embryonic zone の細胞は細胞質突起は発達しておらず， 対照群でみられたように辺縁はスムーズで細長い形態を している (写真19).

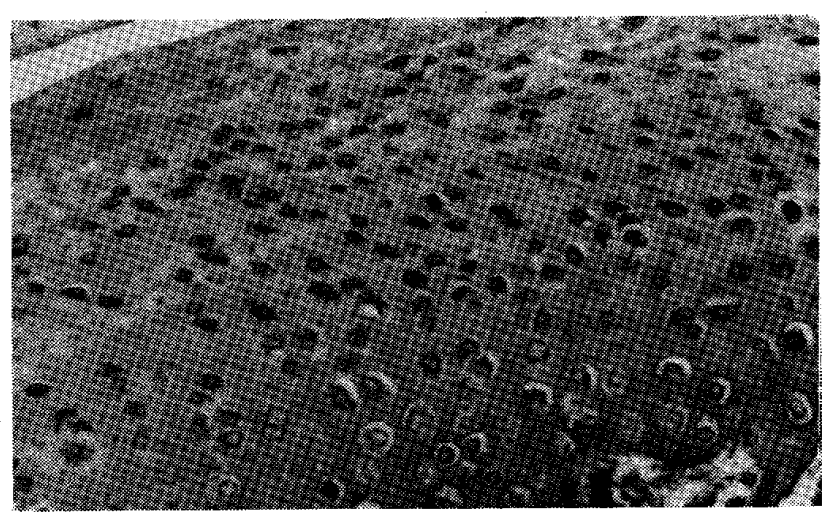

写真17 穾験A群 15 週目所見 $(\times 200)$

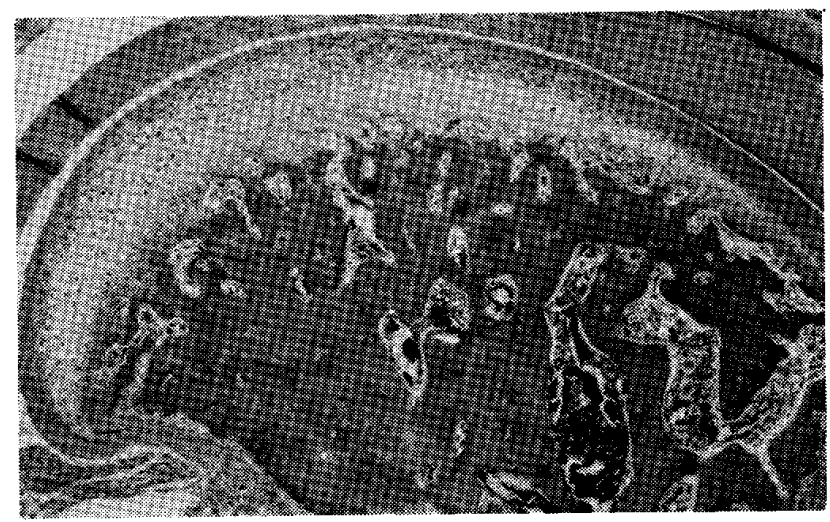

写真18 実験A群 15 週目所見 $(\times 40)$

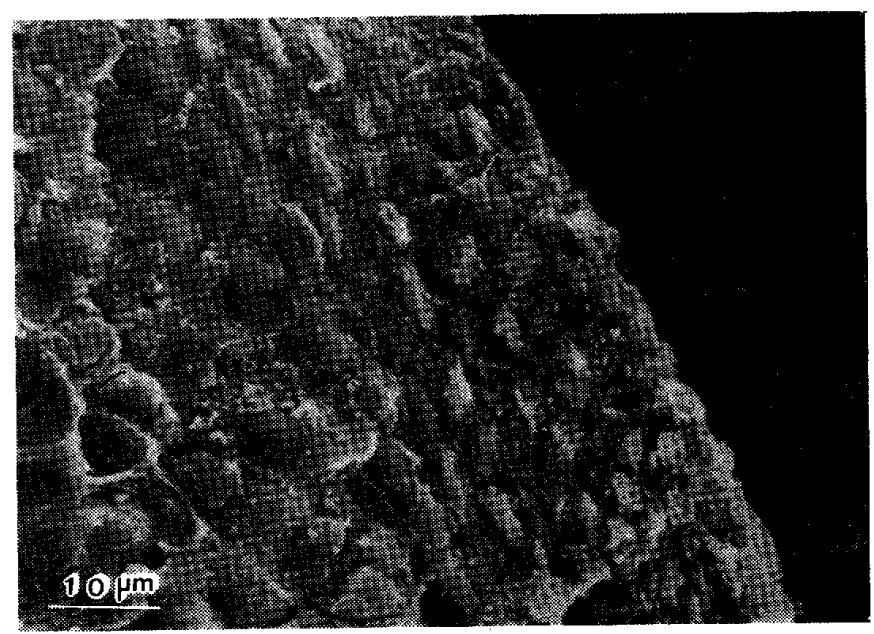

写真19 実験A群 1 週目 SEM 所見

2 週目

中央部内側の articular zone よりの embryonic zone の細胞は 1 週目に較べ細胞質突起はより発達し, 形 態もやや丸みを帯びている。配列は規則的であるが，大 きさは大小不同になっている。また transitional zone よりの embryonic zone の細胞は対照群と同様に細長 い形態をしているものの，大きさが大小不同になってい る. 
また対照群では諗められなかった細胞と細胞小腔との間 に空陌が認められるようになる(写真20) . transitional zone の細胞は対照群と較べて差異は諗められず直径 7 $\sim 10 \mu \mathrm{m}$ の類円形を呈している.

\section{3 週目}

中央部内側の articular zone よりの embryonic zone の細胞の細胞質突起の発達は 2 週目ほど著しくな い，また配列や大きさは 2 週目と同様な所見を呈してい る. transitional zone よりの embryonic zone の細 胞も 2 週目と同椂な所見を呈している.

\section{4 週目}

中央部内側の embryonic zone の細胞の細胞質突起 は 3 週目よりも減少して扔り，大きさは大小不同になっ ている。また，配列も 3 週目より疎で不規則になってい る．細胞と細胞小腔との空陌はさらに大きくなっている (写真21).

6 週目

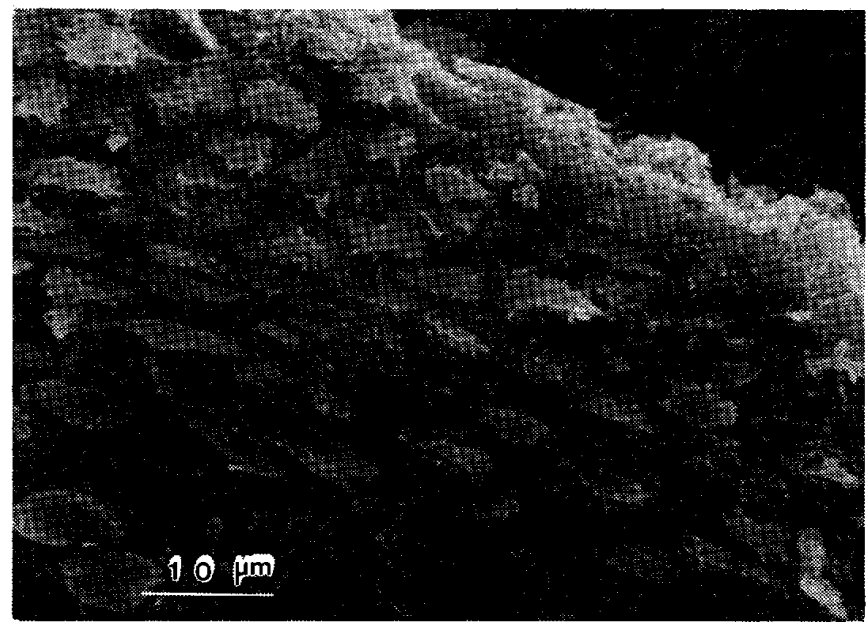

写真20 実験A群 2 週目 SEM 所見

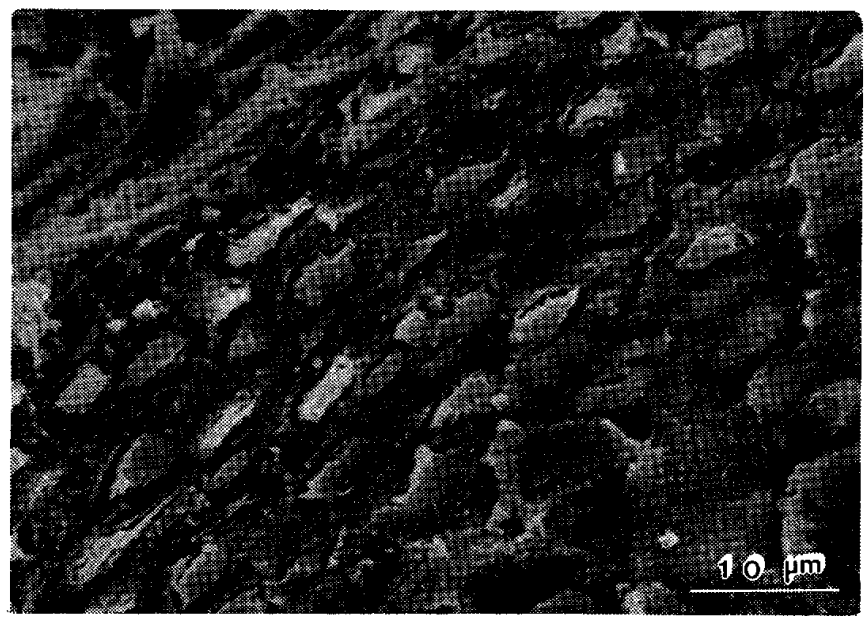

写真21 実験A群 4 週目 SEM 所見
中央部内側の embryonic zone の細胞は 4 週目に較 べ形態はやや丸みを帯び，細胞質突起は減少している. また，配列は密になっており細胞と細胞小腔との空隍も 減少している (写真22).

9 週目

中央部内側の embryonic zone の細胞は 6 週目より 細胞質突起は減少しほとんど認められず，形態もより丸 みを帯びている。

基質の膠原原線維は数本が集まり，小束を形成する傾 向が認められ，乙の小束が膠原原線維閒に散在してみら れる("写真23)。

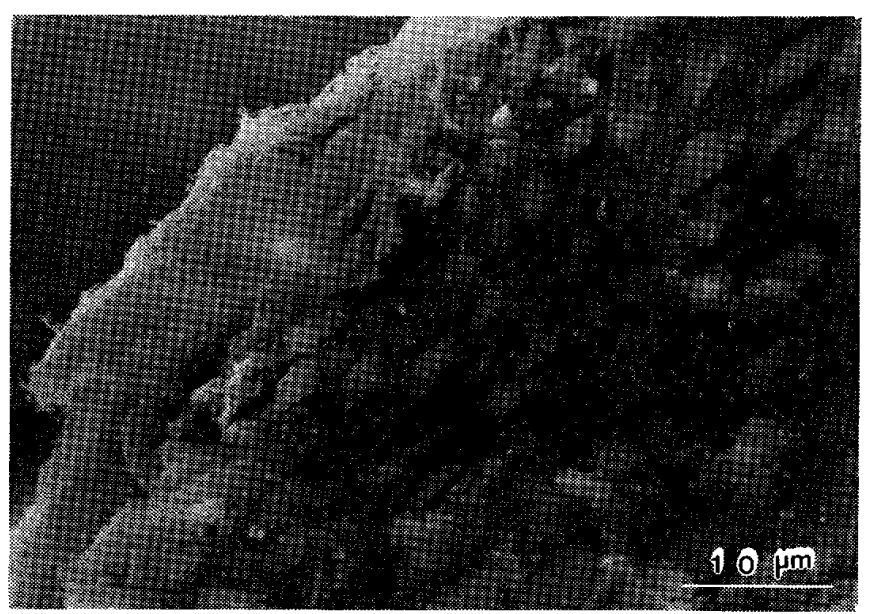

写真22 実験A群 6 週目 SEM 所見

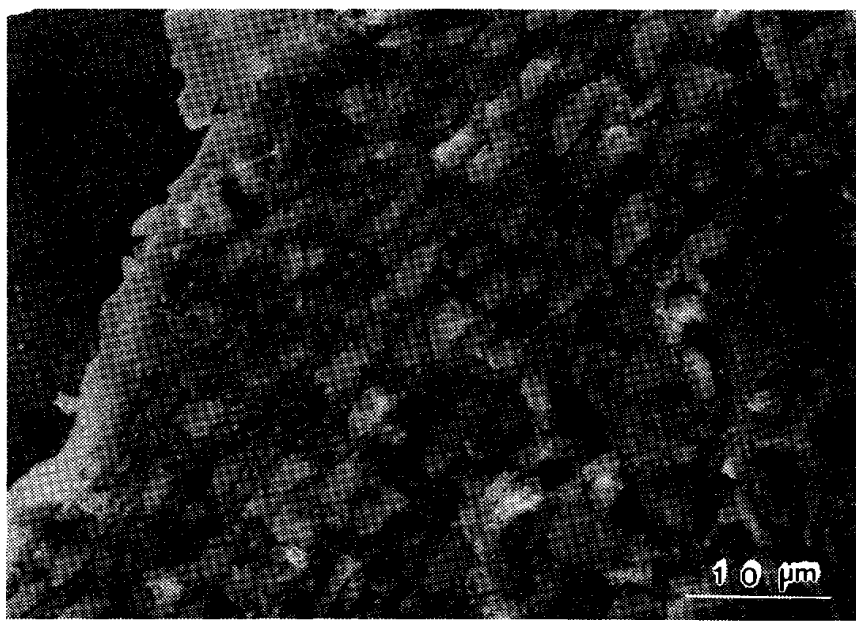

写真23 実験A群 9 週目 SEM 所見

15週日

中央部内側の embryonic zone の細胞は 9 週目と較 べて大きな変化は認められない，基質における膠原原線 維の小束を作る傾向は 9 週目よりも著明になっておら， 一部走行が不規則になった所も認められる（写真24）. 


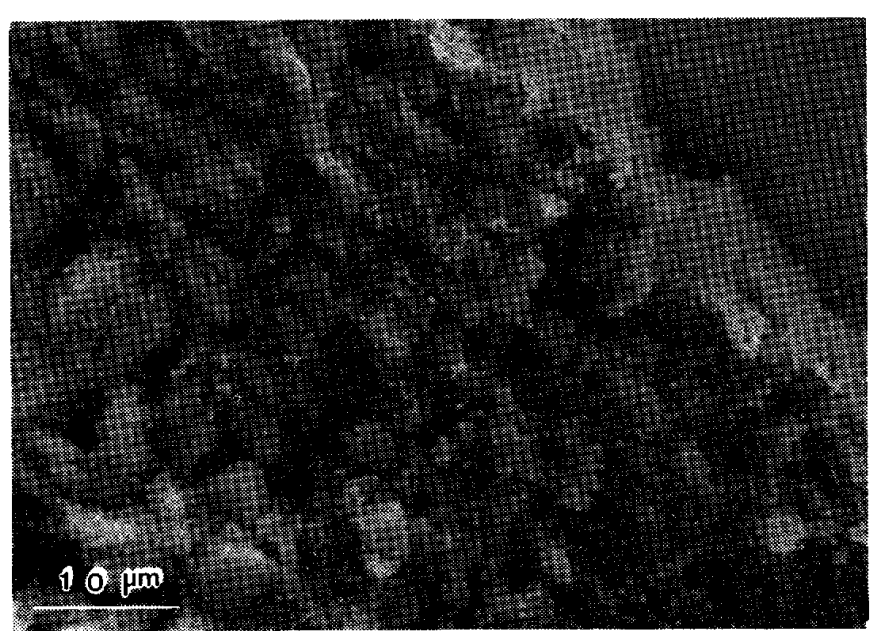

写真24 実験A群 15週目 SEM 所見

IV.実験B群の組織所見

A. 光湿所見

3 日目

下顎頭軟骨層は中央部から内側にかけての transitional zone と hypertrophic zone の㞓さは对照然より

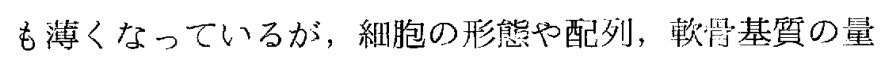
などには特に変化は怹められない，また，層の厚さの減 少程度は hypertrophic zone で著しく, 対照群の約半 分で 4〜 5 層しか認められない.乙のため軟受層全体の 翡薄化をきたしている(年真25)。外側に扔いてはすべ

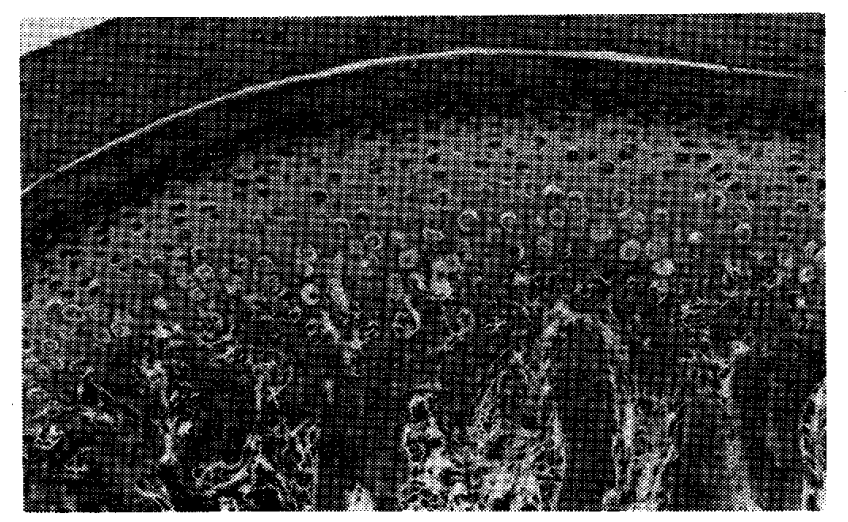

写真25 実験 B 群 3 日目所見 $(\times 100)$

ての層で特に変化は認められない。

骨梁は対照群と同じように，下顎磌表面に重面方向に 規則的に走行している.

内側頸部の外側翼突筋付着部骨緣に冒忣収が認めら れ，骨縁は不規則な鋸雪状を呈しており，その程度は対 照群よりわずか強い。

\section{1 週目}

下顎頭軟骨首中央部の embryonic zone で細胞数の
增加竞認め，層も厚くなっている. embryonic zone 下 の transitional zone でも細胞数は増加しており, 軟 肙基質の増加も琹められるが，全体的にはわずかに層の 厚さを增しているにすぎない，hypertrophic zone の 細胞は 3 日目と較べて一部膨化しており，配列もわずか に不規則になっているが, 愿さは 3 日目と変わらない。 内側では embryonic zone の軟骨基質の増加が認めら れ，細胞数は減少し疎に配列している。しかし，細胞の 形態は対照群と差異はない（写真26）。

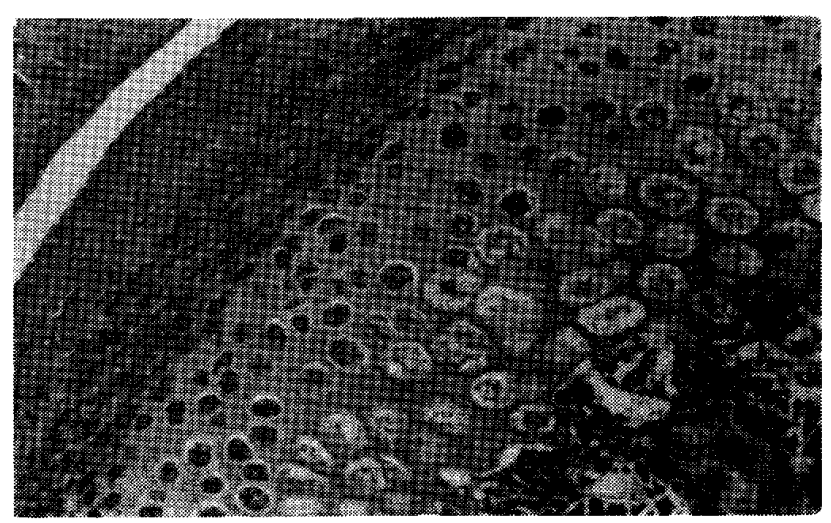

写真26 実験 B 群 1 週目所見 $(\times 200)$

内側頸部の外側翼突筋付着部骨縁の骨吸収の範囲は 3 日目よりも下方に向って広がっており，破骨細胞も広範 に認められる。

\section{2 週目}

下顎頭軟算層中部の embryonic zone の細胞数は 1 週目と較べて減少しておら，軟骨基質の増加がわずか に詡められるが，配列は規則的であり形態の変化は認め られない。その下の transitional zone は軟骨基質の

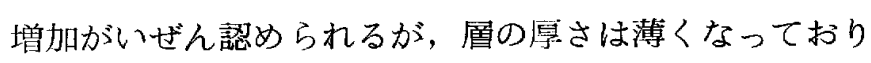
対照群と差異は認めない. hypertrophic zoneは 1 週目 よりも規則的であり，首の愿みも增しているが対照群に 較べるといまだ菲薄である.内側の embryonic zone の細胞形態は丸みを產び，細胞数は減少し，配列は不 規則になっている。また，軟骨基質は 1 週目より著明に 増加しているため, 紐胞の配列は疎となり, transitional zone との境界は不明瞭となっている. hypertrophic zone は非常に薄くなっており $2 \sim 3$ 層しか誌められな い(写真27).

罗梁は太さを增し, 隣接するものと癒着し, その走行 がわずかて不規則てなった所が誋められる，骨髄腔は狭 窄し，下顎頭に占める骨質の割合いが多くなっでいる。

内側頸部の外側翼突笳付着部骨縁における姐吸収所見 はいぜん続いているが，1週目よりもその範囲が小さく 


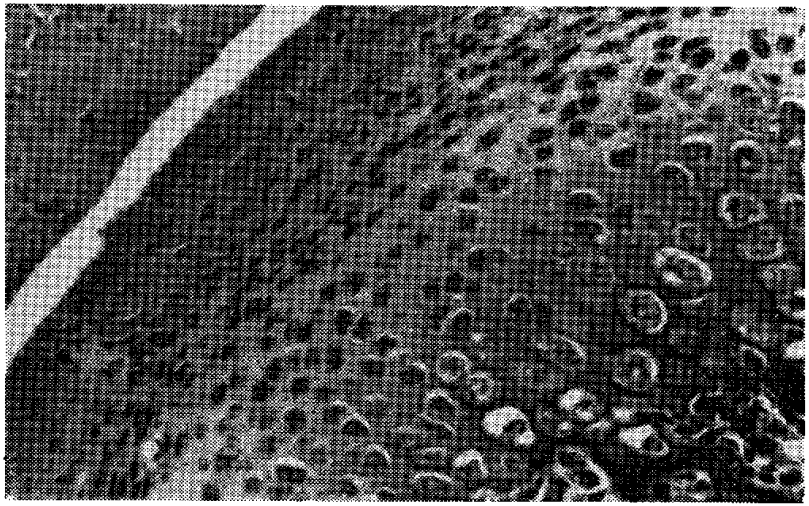

写真27 実験 B 群 2 週目所見 $(\times 200)$

なっている。

3 週目

下顎頭軟骨層中央部の hypertrophic zone が 2 週目 よりもさらに層の厚さを増しているが，いぜん対照群よ りも薄い，内側では 2 週目と同様な所見を呈しておう， 細胞の形態は丸みを帯び軟盈基質の増加が認められる. transitional zone は菲薄化が進み, embryonic zone との境界はさらに不明瞭になっている（写真28）。

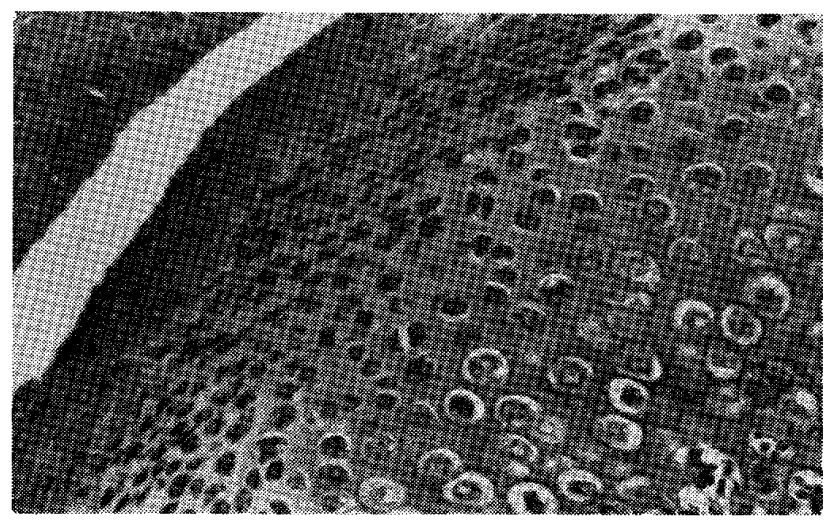

写真28 実験 B 群 3 週目所見 $(\times 200)$

\section{4 週目}

下䫟頭軟骨風内側での変化は最高に達し，その範囲も 中央部にまで拨大している。中央部の embryonic zone の細胞の形態は丸みを帯び，配列が不規則に なっている。一方, embryonic zone 直下の transitional zone, hypertrophic zone は 3 週目と特に差異は 認められない。

内側においてて，細胞の形態はより丸みを帯びたものが 増加し, 軟骨基質の占める割合も増加を示し, 層全体が愿 くなっている．また，配列は不規則で transitional zone との境界はますます不明膫になっている（写真29）。

骨梁の走行は対照群に較べて不規則であるが，全体的

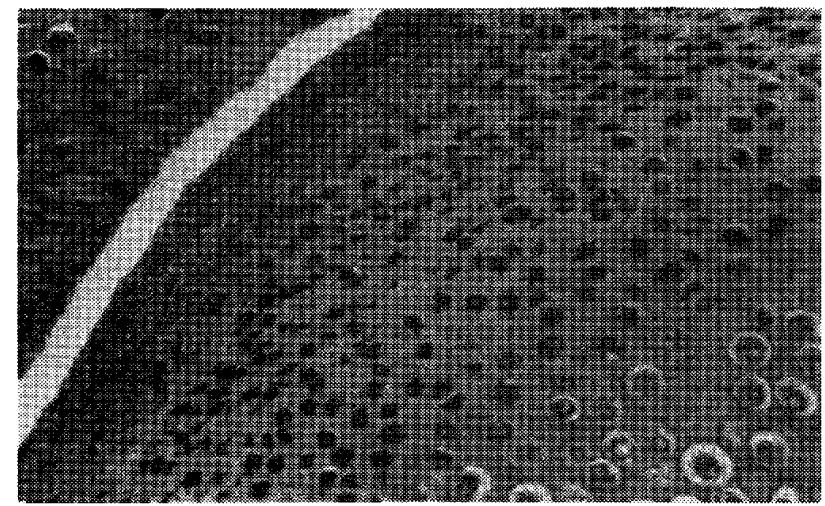

写真29 実験 B 群 4 週目所見 $(\times 200)$

に太さを增し，骨髄腔はさらに狭く，小さくなる傾向を 示している。

内側頸部の外側翼突筋付着部骨緣における骨吸収所見 は軽微となり，対照群との差異はほとんどない。

6 週目

下顎頭軟骨層の embryonic zone に扔ける変化を示 す範囲は小さくなり，中央部内側までの限られた範囲に なっている。また, embryonic zone の細胞の配列は 4 週目に較べわずかに規則的になっているものの，形熊 はより丸みを帯び, 染色性は低下し, transitional zone の細胞よりわずかに小さいぐらいで形態的には区別でき ない，その下の hypertrophic zone の厚さはいぜん薄 く 3 週目, 4 週目と変化は認められない(写真30). し かし, 中央部の hypertrophic zone は 4 週目よりもさ らに薄くなっている。

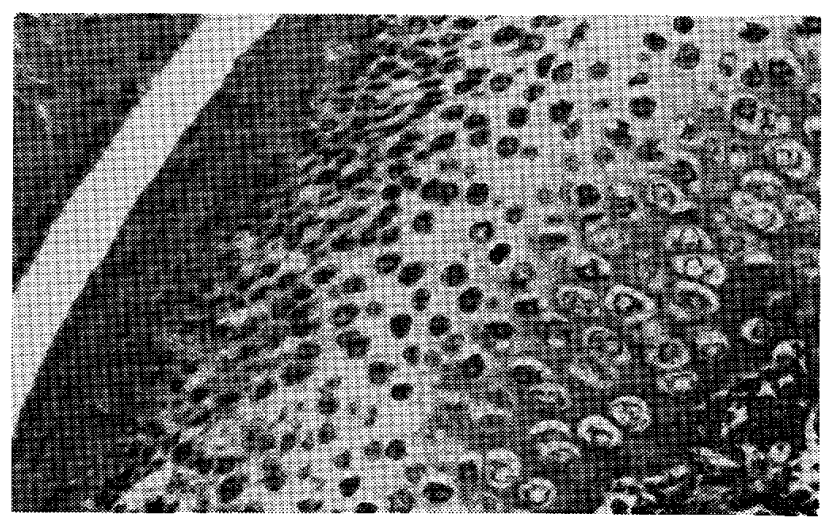

写真30 実験 B 群 6 週目所見 $(\times 200)$

9 週目

下顎頭軟骨層中央部では transitional zone, hypertrophic zone の厚さが非常に薄くなっており, 対照群 に較べて菲薄化している. 一方, 内側では embryonic zone の軟骨基質の増加が著明となっておら，層の厚さ 


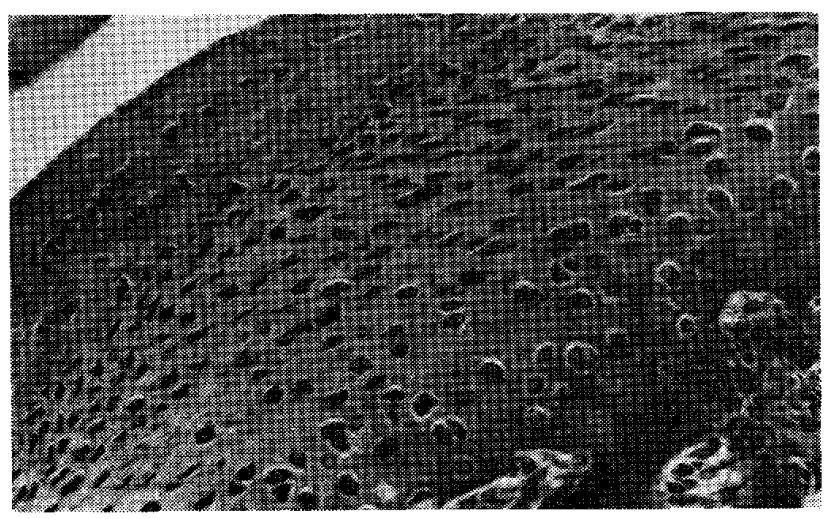

写真31 実験 B群 9 週目所見 $(\times 200)$

も厚くなっている，また，紲胞の配列は疎にかつ不規則 となり，形態や大きさも不同になっている. transitional zone, hypertrophic zone の唇さは非常に薄くな っている (写真31).

下顎頭の骨化は中心部骨梁の成長と骨䯣腔の狭窄によ り進行し，対照群に較べて著しく，特に内側で著明であ る.

内側頸部における外側翼突筋付着部骨縁の骨㥸収は軽 微となっている(每真32).

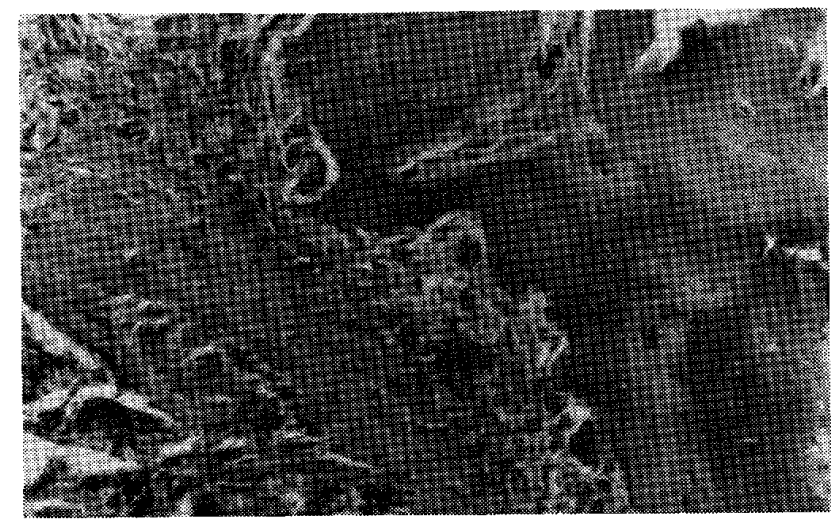

写真32 実験B群 9 週目所見 $(\times 200)$ 内側頸部の外側翼突筋 付着部骨縁

\section{5週目}

下顎頭軟骨層中央部の embryonic zone は染色性が 低下しており，細胞の形態，配列も不規則で，細胞数が 減少し層の厚さは薄くなっている. hypertrophic zone の軟骨基質は増加し，細胞数は少なく疎に散在して羿め られる.内側では embryonic zone と transitional zone との区別はできず, 細胞の形態は類门形を呈し, 9 週目に較べ軟骨基質の量は顕著に減少し, 厚さは薄く なっている (写真33).

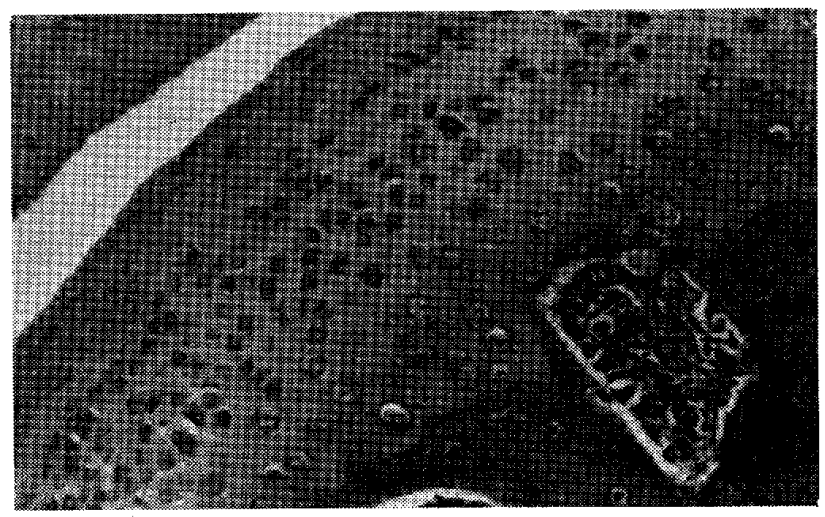

写真33 実験 B 群 15 週目所見 $(\times 200)$

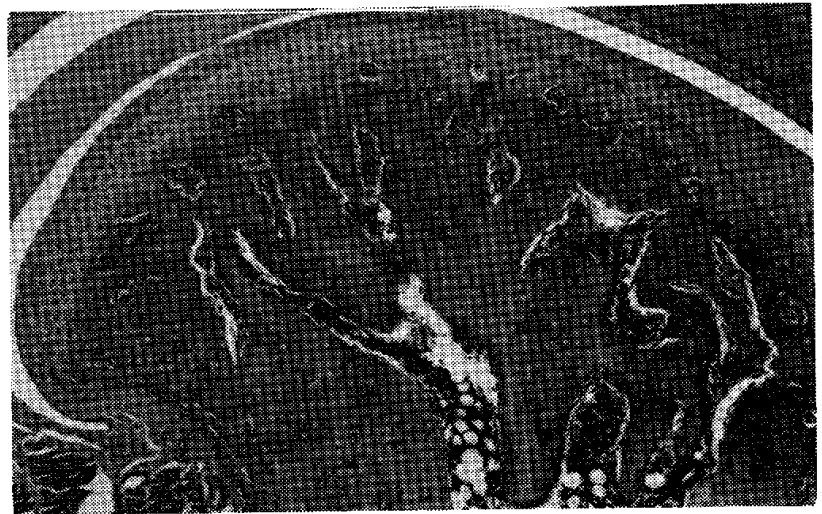

写真34 実験 B 群 15 週目所見 $(\times 40)$

下顎頭の骨化はさらに進み，対照群に較べて骨髄腔は 極めて㹨小化し，さらに緻密化が進んでいる(写真34).

内側影部の外側翼突筋付着部骨縁は平坦となり骨吸収 像は認められない。

B. SEM 所見

3 日目

内側の embryonic zone の細胞の形態は対照群と較 べ，幅がやや短かく細長い形態のものが認められる．紏 胞の配列は対照群よりもわずかに柾になっているが規則 的である．基質の膠原原線維の走行は対照群と同じよう に前後方问に多く走行している.

1 週目

内側の embryonic zone の基質の膠原原線維の走行 が一部不規則になっており，内外方向に走行する線維も 多く認められる.また, 線維が数本集まり束になった所 も認められる。一方, 細胞は基質の膠原原線維に取り囲 まれているため，輪郭は不明瞭になっており，配列は対 照群よりも眯になっている(写真35).

2 週目

内側の embryonic zone の基質の膠原原線維の走行 は 1 週目に較へ，前後方向に走行するのが多くなり，そ 


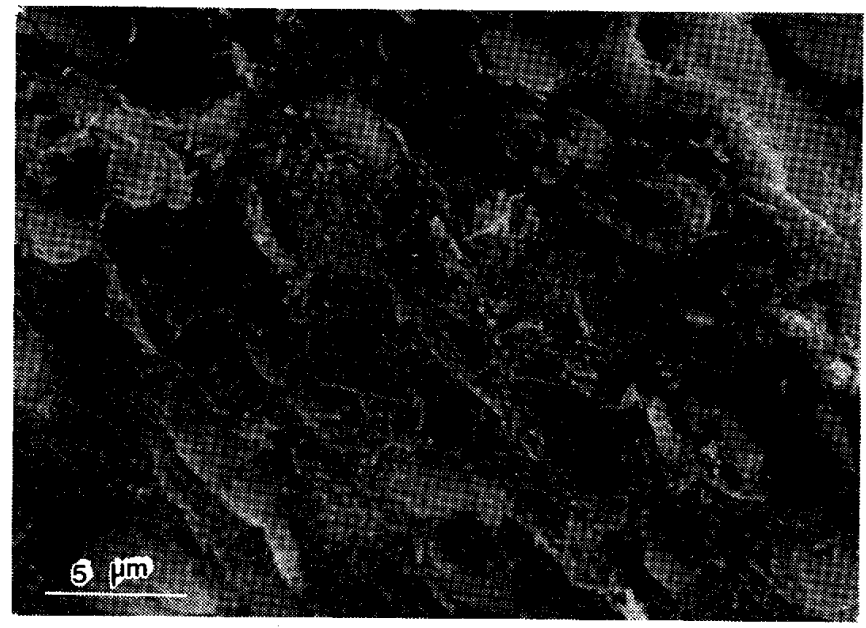

写真35 実験 B 群 1 週目 SEM 所見

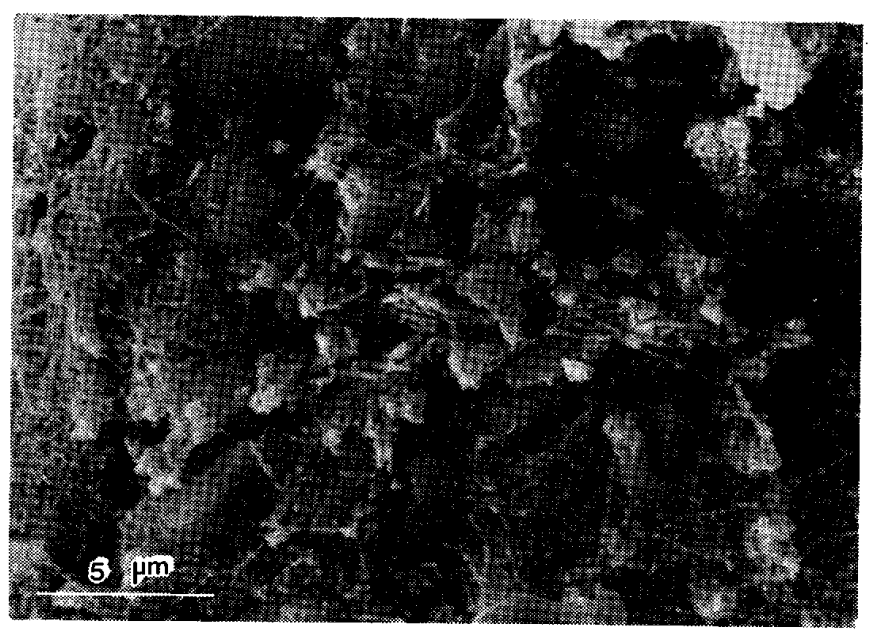

写真36 実験 B 群 2 週目 SEM 所見

の線維の数本が集まり束となって小束を形成している. また, 細胞は 1 週目よりも基質の膠原原線維に取り囲ま れており，細胞を取りまく膠原原線維は 1 週目よりその 数を増し, 細胞の輪郭はさらに不明膫になっでいる、細 胞の配列は 1 週目よりも不規則である（写真36）。

3 週目

内側の embryonic zone は 2 週目と同様な所見を呈 しており, 基質の膠原原線維は 2 週目よりわずかに前後 方向に走行するものが多くなっている.

4 週目

内側の embryonic zone の基質の膠原原線維の多く は前後方向に走行して抢り，線維の小束をなす傾向は 2 週目， 3 週目よりも著明になっている。そして，この小 束は太さを增し, 直径約 $2 \mu \mathrm{m}$ ぐらいになっているのも 認められる.また，小束中の個々の線維同士が癒着した ような所見す缌められる。

細胞はいぜん基質の膠原原線維に取り囲まれており輪

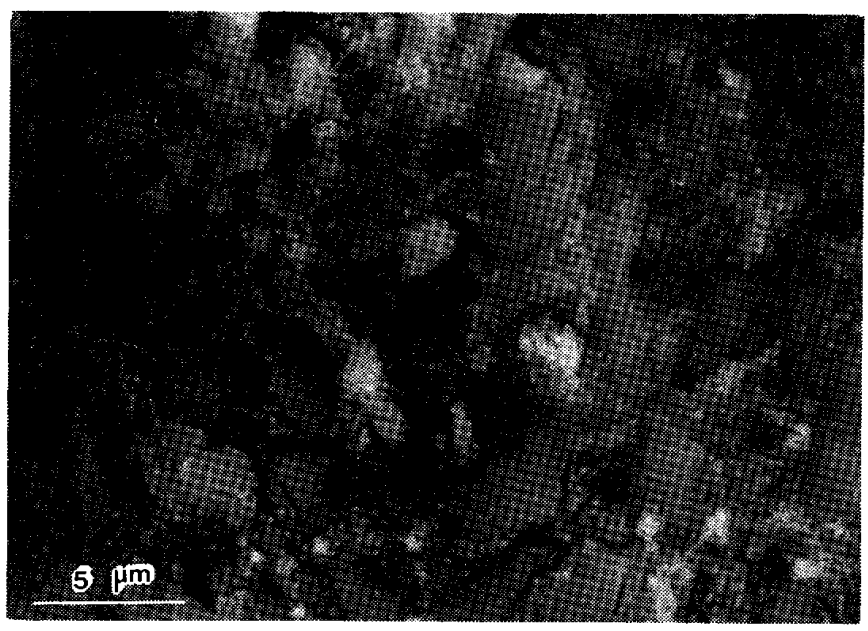

写真37 実験 $\mathrm{B}$ 群 4 週目 SEM 所見

部は不明瞭である(与真37).

6 週目

内側の embryonic zone の基質の膠原原線維にいぜ ん小束を形成したものが琶められるが，その程度は 4 週

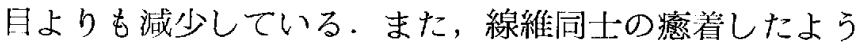
な所見は認められず，線維ならびに小束の走行はやや規 則的になっている (守真38).

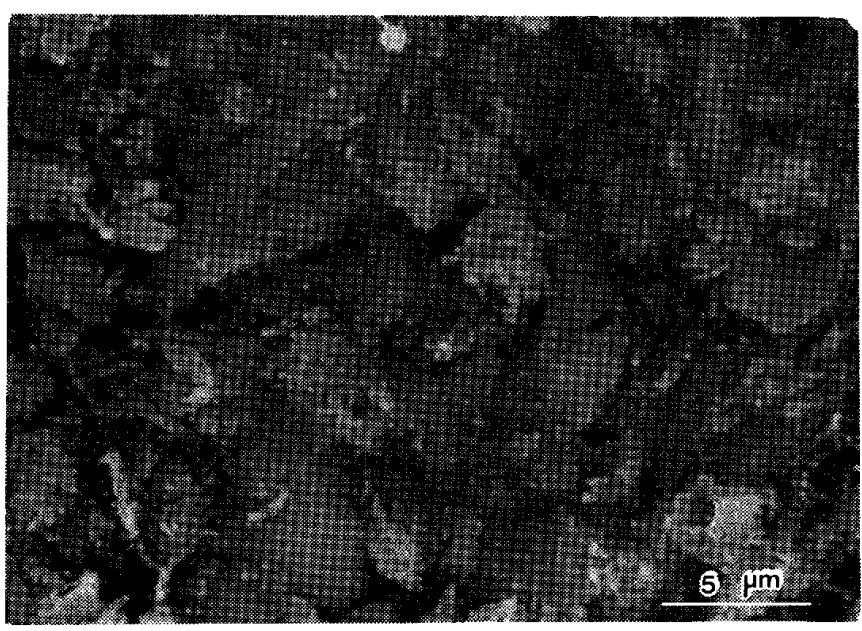

写真38 実験 B 群 6 週目 SEM 所見

9 週目

内側の embryonic zone の基質の腃原原線維は前後 方向に多く走行しており，6週目に較べて規則的で対照 群の走行と同様であるが，対照群よりも密となってい る、また，小束をなす線維は誌められない。細胞の形態 は対照群よりも丸みを帯び，配列は疎で不規則である (写真39).

15週目

内側の embryonic zone の基質の膠原原線維は前後 


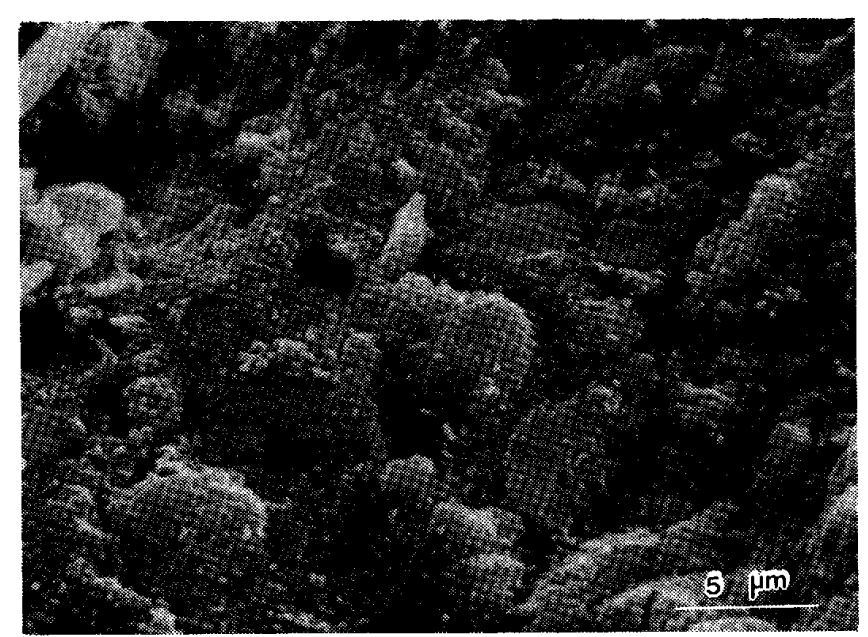

写真39 実験B群 9 週目 SEM 所見

方向に多く走行しており，対照群と同様な所見を呈して いる. 細胞の形態は類円形を呈しており, transitional zone の細胞の形態に似ている.

\section{総括ならびに考察}

実験的茵牙欠損や賋合面削合を加えて咬合異常を惹起 させ，顎関節への影饗について病理組織学的に観察した ものには, Breitner $(1941)^{32)}$, Avant ら $(1952)^{15)}$, Cimasoni (1963) ${ }^{16)}$ ，Furstman (1965) ${ }^{171}$ ，小野ら $(1967)^{18}{ }^{1}$ ，檜辿 (1968) ${ }^{191}$, 鈴木 $(1971)^{201}$, 河野 (19

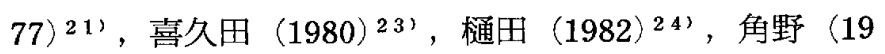
83）22）らの報告がある.

これらの報告では, 䂓関節における種々の病理組織学 的変化が明らかにされている. その変化は顎関節を構成

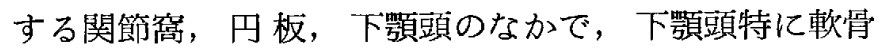
居に最も多様な変化が虫められている，そこで著者は， 咬合異常が顎関節に及ぼす影響をさらに詳細に検索する ため，SEM を用いて下顎頭特に軟骨層を中心に観察し た。

\section{I ．実験方法について}

この種の実験では, 動物の種類, 年歯, 欠損部位など が，実験結果に大きな影響を与えることは広く知られて いる．また下顎頭は成長発育の影響を受けやすい部位で ある、そこで発育による影響を最小に抑え，実験による 変化を十分に把握するためには，実験の時期としては可 及的に顎関節の形態が完成した時期を選ぶ事は意義ある ことと考える. Furstman (1966) ${ }^{33}$ ），三木 $(1972)^{34)}$ らによれば，ラットの下顎頭は生後50日目でほぼ顎頭 の形は整い，生後60日目には特有の形態を有するように なると報告している，そてで著者は実験の時期をラット の下䫟頭の形態がほぼ完成する生後 60 日に設定した。
欠損部位についてみると，Furstman (1965) ${ }^{171}$ はラ ットで, 樋田 $(1982)^{24}$ 'はサルで, 両側歯牙欠損を作成し 観察しているが，いずれも左右顎関節の変化に明らかな 差異を認めていない，著者の実験 $\mathrm{B}$ 群の如く函牙欠損に 加えて，左右切雪の削合を行なった報告はいまだみられ ないが，左右対称的な咬合変化による左右顥関節への影 響は注同じと考元，各ラットの右下箩頭を SEM 用， 左下罘頭を光顕用として対比観察した。

\section{SEM 用試料作製法について}

下䫇頭をSEM を用いて観察した研究には田口 (1980) 26)，塩田ら $(1980)^{25}$ 'の報告がある. その試料作製法 は, グルタルアルデヒド・オスミウム酸二重固定, 脱 水, 凍結割断, 臨界点乾燥, 蒸着の後観察している.し かし，実際に試料を作製し観察してみると，試料の鋭縁 部にチャージアップが起とりやすい. そてで試料にもっ と導電性を持たせる必要があると思われた。小嶋 (1981) ${ }^{35)}$ はラットの脛骨骨端軟骨を用い，固定後タンニン・ オスミウム法で導電染色を施し，凍結割断を行ない，無 蒸着で観察し良好な結果を得たと報告している。そてで 今回，さらに試料導電性を持たせるため，凍結割断 後, タンニン・オスミウム法で導電染色を施し, 割断面 に Au-Pd イオンコーティングを行ない観察した.乙 の方法は割断後の操作が増えるため, 割断面に artifact を生じる可能性が大きくなるが，試料に導電性を持たせ るには良い方法と考える。また今回 embryonic zone を観察する場合，表首の articular zone はトリミング した方が良好な結果が得られた。というのは，試料を割 断した場合 articular zone と embryonic zone の境 で段差ができることが多く， embryonic zone が観察 しにくかった. この段差は articular zone が線維性被 膜であり, embryonic zoneと硬さが違うためできると 思われる．また articular zone は 1 枚の膜として容易 に下顎頭より剝離でき，トリミングは比較的簡単であ る。トリミングの際，下顎頭表面に artifact を生じる と思われるが，観察する割断面には特に問題はないと考 える。

\section{III. 体重変化について}

ラットを用い雨牙抜去や咬合面削合を行ない，実験的 に咬合異常を惹起させた際の体重変化についての報告を みると，檜山 $(1968)^{191}$ ，鈴木 $(1971)^{201}$, 河野 (1977) 21)などは，対照群と差は見られないと報告している。 一方, 濱田 $(1965)^{36)}$ は拔霜後 $2 \sim 3$ 日目頃までは, 体 重が減少し，4〜9日目頃から増加して回復の傾向がみ られ, 曾牙抜去前の体重に回復してくる. 以後, 増加率 
は対照群より低いと報告している。

本実験では，奏験 A群， B 群とも 3 日目までわずかに 体重の減少がみられるが，乙れは実験による外科的侵襲 のため，一時的に摂食量が減少するためと思われる．檜 山 (1968) ${ }^{19 \prime}$ は実験後 1 か月, 鈴木 $(1971)^{20)}$ は抜歯後 20日目，河野（1977２1'は10日目に体重を測定している が，すでに体重が回復した後と思われるので，著者の場 合と比較は出来ない。しかし，実験により大なり小なり の外科的侵襲は加わるので, 実験直後の体重の減少は容 易に想像できる。

その後の体重の増加傾向は対照群と同じであり，増加 率はわずかに対照群よりも低いものの，全身的な栄養障 害はないと考えられた。

IV. 下額頭各部における変化について

実験動物の種類や雬牙欠損の状態により，下顎頭各部 に加わる機械的刺激に差が生じ，下顎頭各部の軟骨層の 変化にも差暴が生ずることは当然考えられる．Furst-

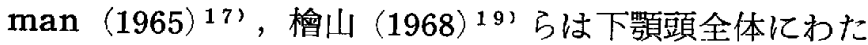
り軟骨層は経時的に薄くなると述べているが，下顎頭の 各部位における軟骨層の変化の差異については述べてい ない.鈴木 $(1971)^{201}$ も下顎頭全体にわたり軟骨首は薄 くなるが，下顎頭後方部において彷来の報告よりも愿い 傾向がみられたと述べているに過ぎず，下顎頭前方，中 央に分けた記載はしていない，以上のように，ラットを 用いた実験では軟骨層を一塊としてその厚さについて記 載したものが多く，細胞の形態，配列や軟骨基質の状態 などについて記述したものは極めて少ない，わずかに Avant ら (1952) ${ }^{15}$ が下顎頭前方部に靯骨層の線維形 成を報告し，角野 $(1983)^{22}$ が下顎頭の中央頂部に線維 性構造が認められず，軟骨芽細胞への移行像を示す細胞 の出現がみられたと報告しているにすぎない，

一方サルを用いた奏験では，喜久田 $(1980)^{23}$ が抜蒾 側の関節頭内側後隅角部下方に特異的な軟骨層の変化が 認められたと述べている，樋田（1982（24'は関節頭前方 部より中央狭窄部にかけて，先人の報告と同様に経日的 な軟骨層の菲薄化を喼め, 後方部では早期より軟骨層の 肥厚化が進み，60日目で最大となるが，以後，韭薄化を 示し，また後縁では経日的に軟骨層が下方に向かって新 生していたと述心，同変化を霜牙欠損により関節窩にお ける関節頭の位置が不安定となり，関節頭各部に加わる 正常時と異なった機械的刺激の差がこのような変化をも たらしたものと考えると述べている。

本実験において，実験 $\mathrm{A}$ 群では下顎頭の中央から内側 にかけて, また実験 B 群では内側の軟骨層に特異的な変
化が羿められた。しかし，外側においては実験 $\mathrm{A}$ 群，B群

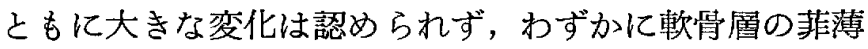
化が誻められた。この原因については，樋田（1982）24 の理論に加えて, 解剖学的に下顎頭と関節窩との間隙が 下顎頭の外側部では広く，中央部より内側部に行くに従 って狭くなっているため，咬合異常による機械的刺激は 中央部から内側部にかけて, 強く加わりやすいためと考 えられる・

\section{V. 下額頭軟骨層の変化について}

Articular zone について, 檜山（1968） ${ }^{19}$ は経日的 に薄くなり，その程度は前歯の削合を行なった群の方が 強いと述べており，線維束の走行などについては言及し ていない.鈴木（1971）201は抜崡側で線維走行の乱れ が見られる傾向があったと述べている．Furstman（19 65） ${ }^{171}$ ，河野（1977）21'らはこの層については言及して いない，樋田（1982）24) は後方部で線維束の波状走行を 認めているが，一般的に他の軟骨層に較心゙て変化は小さ いようである。

著者の所見でも，乙の層に大きな変化は想められず， わずかに実験A群の 6 週，9週目に中央部内側よりに線 維束の走行の乱れを認めたにすぎないままた咬合異常が より大きいと考えられる実験 B 群において, 特に変化が 認められなかったことから，乙の層は下頡頭に加わった 機械的刺激にあまり影響を受けず，下䫁頭軟骨の表面を カバーし，保護するものと思われる.

Embryonic zone は下顎頭軟骨層において細胞增殖 の最も盛んな層であるといわれており，下顎頭に機械的 刺激を与えて， ${ }^{3} \mathrm{H}$-thymidine 孝用いたオートラジオグ ラフィーによる研究で, Folke ら $(1966)^{37}$ は下顎の成 長が embryonic zone の細胞增殖によりコントロール されているようであると報告している．また野口(1970) 38) は矯正用 elastic thread を用い下枵頭に外力を加 え, ${ }^{3} \mathrm{H}$-thy midine のラベル法により観察し embryonic zone に多数の整識された細胞を認めている. 今村 $(1973)^{39)}$ はembryonic zone での軟骨基質内線 維形成が，同層の高い細胞增殖率と相まって，下顎頭の 成長に少なからず貢献しているものと推察されると述べ ている.

実験的雪牙欠損による頛関節への影響についての研究 では，サルを用いた実験においいて，喜久田（1980２33は 非抜歯側の後隅角部に細胞の増加, 細胞配列の不規則化, 間質線維の増加なよ゙を認めており，樋田 (1982) 24)も後 方部において同様な所見を報告している。しかし，ラッ トを用いた奏験においては，乙の層の変化について特に 
言及した報告はみられず，菲薄化が起ると述べているに すぎない。

著者の兴験ではこの層に最も大きな変化が認められ た.すなわち，奏験 $\mathbf{A}$ 群光顕所見で 1 週目より中央から 内側にかけての articular zone に接する embryonic zone に丸みを帯びた細胞が出現し，SEM 所見では articular zone よりの embryonic zone の細胞に細胞質 突起の著明な発達が見られた.SEM による観察でこの 風の紐胞形態を田口 $(1980)^{26}$ ' は圧平された紡銛形を呈 していたと述べており，塩田ら（1980）25)はこの層の細 胞については観察しておらず，細胞質突起の発達した紐 胞について述べたものはみられない，しかし，TEM に よる観察で，塩田ら $(1980)^{28)}$ はこの層の細胞の間葉系 細胞加ら軟骨芽細胞への分化による移行過程と考えら机 る細胞は楕円形で, 細胞辺縁ではいわゆる三角波型の細 胞突起がみられ，一部の突起は基質内に長く伸びていた と述べている. 森田 $(1982)^{29}$ もこの層の細胞に, 長い 細胞突起を有している所茪を認めている．また，乙の層 の基質の膠原線維の形成に関して森田 $(1982)^{29}$ は線維 層に比心゙，よく発達した細胞小器官を有していること と, AL Pase 活性が認められることから, 活発な基質 形成能を有すると述べ， ${ }^{3} \mathrm{H}$-proline を用いたオートラ ジオグラフィーによる研总で今村 $(1973)^{391}$ は transi tional zone についで, 軟骨基質内線維形成にもこの層が 大きく貢献しているととがうかがわれると述べている.

本実験において，ての層に丸みを帯びた細胞が認めら れて基質の増加が認められたととから，との紐胞が基質 形成に関係があると考えられた。

基質の翏原原線維の走行については，田口（1980）261 が関節面とは全く無関係に膠原原線維が走行し，あたか もスポンジ様構造を呈していたと述べている。

本実験の対照群における, embryonic zone では下顎 頭の前後方向に多く走行しており，transitional zone では田口 $(1980)^{26)}$ と同じように走行していた。また夷 験 B 群 2 週目より認められた著明な膠原原線維の小束化 は，田口 $(1980)^{26)}$ の報告ではあらわれなかった。また 本実験の対照群においても認められなかったととから， 切米の削合を併せて行なったととにより，下顎頭に加わ る機械的剌激が強くなった影響と思われる。

実験 A 群では基質の膠原原線維の増加が認められた が，線維の走行においては，あまり大きな変化は認めら れなかった。しかし，実験 B 群では線維の走行の乱れ や，小束の形成が琶められたととから, embryonic zone において, 加わった機械的刺激の強さの程度によっては
基質の膠原原線維の増加のみで緩衝できるが，さらに強 くなると, 数本の線維が束となってその機械的刺激を緩 衝するものと考える。

${ }^{3} \mathrm{H}$-proline を用い，オートラジオグラフィーによる

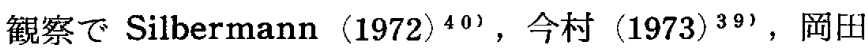
$(1977)^{41)}$ らは，いづれも全軟骨層のうち transitional zone が最も多く ${ }^{3} \mathrm{H}$-proline を取り込むことで一影し ている.また今村 $(1973)^{39 \prime}$ はこのことを transitional zone が細胞堌殖よりも基質形成面で重要な働きをして いることを裏付けるものであると述べている．乙の点に 関しては従来の TEM による観察でもよく発達した粗 面小胞体や Golgi 体などが観察され，活発な基質形成 を，ての屏が行なっていることは通念となっているよう である。

粜牙欠損による機械的刺激がこの基質形成にも影響を 与えるととは当然考えられるが，従来の報告をみると， ラットを用いた実験において，層の菲薄化を記載したも のが僅かに認められるにすぎず, 紼胞形態, 基質の変化 について記載したものはみられない．本実験の光顕所見 では，軟骨基質のわずかな増加が認められたが，著明な 変化は認められなかった，著者の SEM に上る観察で も, embryonic zone で諗められたような, 紐胞形態， 基質の膠原原線維の変化などはみられず, 対照群との差 異は認められなかった。

これはこの層の基質の膠原原線維は前でも述べたよう に，関節面とは全く無関係に走行し，あたかもスポンジ 様構造を呈しておら，軟骨細胞を含む小腔を取り囲むよ うな形態をとることに起因すると考えられる．すなわ ち，この様な構造は下顎頭に加わる機械的刺激を緩衝す るのに適した構造と思われ，本奏験で創り出された程度 の機械的刺激の強さでは, articular zone と embryonic zone で緩衝されて，乙の層の膠原原線維の走行を 乱すほどの強さではなかったと考えるてとが妥当であろ 5 .

Hypertrophic zone には細胞増殖能や基質形成能は ほとんどなく，基質の石灰化に関与していると考えられ ている。また，成長とともに軟骨層の菲薄化が進むとと は周知のことで，さらに，実験的雬牙欠損のみならず， 種々の実験的咬合異常や機能異常によっても軟骨層の菲 薄化は著明に進行する. 今村 $(1973)^{39)}$ はラットを用い， 下額遠心咬合を誘導させ，深沢 $(1980)^{42}$ はラットを用 い，閉口運動に関与する笳群を切除し下顎頭軟能を観察 した実験で，特にこの層の菲薄化が大きかったことを述 へ，その理由として，今村 $(1973)^{39}$ はこの層内の個々 
の細胞がもともと極端に肥大しているため，わずかな細 胞数の変動も大きな厚径の変動となって現われるのであ ろうと述べている. さらに embryonic zone $\rightarrow$ transitional zone $\rightarrow$ hypertrophic zone という細胞の流 れが, 外的刺激により影響を受けて, transitional zone からの流入練胞と erosion zone での軟骨吸収とのバラ ンスが崩れたためと思われると述べており，hypertrophic zone の細胞数は embryonic zone の細胞増殖と関 係が深いととを示唆している.しかし，一方では Folke 弓 (1966) ${ }^{371}$ ，野口 $(1970)^{38)}$ らは外的刺激で embryonic zone の細胞增殖活性が高まると報告しておう，細 胞増殖にはある程度の外的刺激が必要と考えられてい る.

本実験で, 実験後 3 日目までA群, B群ともに層の厚 さが薄くなったてとは, 体重の減少からも考えて, 実験 による外科的侵襲により，ラットが咬合をあまり営ま ず，下䝷頭に加わる刺激が減少したため, embryonic zone からの細胞流出が減少したためと考える。また， その後 3 週目まで愿さの増加が認められたことは外科的 侵襲の影響も徐々になくなり，ラットが咬合を営むよう になった結果, embryonic zone での細胞増殖が活発に なったため，流出細胞数が増加したためと思われる.

Erosion zone ならびに下顎頭の骨化についてみる と,実験的菌牙欠損によって観察した Furstman (1965) 17) は下顎頭の骨化が進行したてとを認めているが，檜 山（1968） ${ }^{192}$ によると逆に骨化が障害されたと報告し， 正反対の見解がある。著者の場合は骨化の著明な進行が みられた。この違いは実験方法，実験開始時の年秢など の違いによると著者は考えた。すなわち，檜山（1968） ${ }^{19)}$ は生後 45 日 \pm 5 日のラットを用い，片側雨牙欠損圭 惹起させた実験において，下䅡頭の骨化が障害された理 由として, 二次骨梁の形成が低下したのは，骨頭部軟鹃 層の萎縮により，量的にも一次骨梁の形成が不足したて と，形成された骨梁が上下にのびる規則的な形態をとら なかったこと，また形成された二次骨梁に，適当な刺激 がなかったため，その後の骨添加が咬合を営んでいる側 ほど明らかでなかったてとなどによると述べている。

確かに，檜山（1968）19）の実験で使用しているラット は成長期であり，骨梁形成が旺盛な時なのでこの時期に 実験を行なえば骨梁形成に障害が出ると考えられ，また 実験方法も片側曾牙欠損のため実験側下罰頭に加わる外 的刺激が減少するかもしれない，しかし，本実験で用い たラットは下顎頭の形態がほぼ完成した時期であり，成 長期のラットに較べれば骨梁形成は減少しているため，
実験による骨梁の形成障害は少ないと考えられる。また 実験方法においても，著者の実験は両側曾牙欠損のた め，下擷頭に加わる外的刺激は懀山（1968） ${ }^{19 !}$ の場合と は逆に増大するものと考えられる。

一般的に下顎頭の骨化には外的刺激が重要であると言 われており，岡田(1977）411 は生後28日のラットを用 いて，下額頭部を同腹ラットの背部皮下に移植し，下䋶 頭に加わる機能的な要因・外的要因を断った場合，下額 頭での内軟骨性骨形成はほとんどみられなかった事か ら，下顎頭の形態，軟骨形成の保持，および骨改造に関 しては, 機能的な要因・外的要因が強く関与しているこ とが示唆されたと述へてている．本実験の結果からも，外 側に較べて内側での骨化が強かった。乙れは，軟骨層の 変化からも考えて，外的刺激は内側の方へ強く加わった と考えられる。乙の事からも，下顎頭の胃化には外的刺 激が強く影響することが示唆された。

VI. 下䫁頭頸部の骨吸収について

従来の実験的雨牙欠損による報告で，下顎頭頸部に骨 吸収を認めたものが散見される、ラットを用いた実験で は, Furstman (1965) ${ }^{17}$ ，鈴木 $(1971)^{201}$ が報告して いるが，いずれも片側雬牙欠損による咬合異常によるも のである．しかし，著者の如く両側奥牙欠損による咬合 異常で報告されたものはみられないようである。そし て，骨吸収の原因について，Furstman（1965）17”は下 䪽骨の強い側方偏位を防止するためと述べ，鈴木 (1971) 201 は外側翼突筋付着部に吸収窝を認め，咬合異常によ る神経筋機構の不調和あるいは咀嚼筋の協調性の掊失が 誘因となり起ると推定している.

サルを使った実験では，樋田 $(1982)^{24}$ が両側歯牙欠 椇を作り観察し，同㥞な骨吸収を認めその原因につい

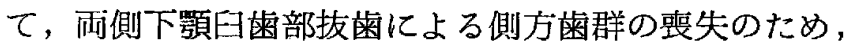
下顎が常に不安定な状態におかれ，顎間機能に不調和が 生じたための変化であろうと述へてている．実験動物が異 なるため，一様に評価することは危険がない訳ではない が，著者も同様な見解をもつものである。つまり本実験 においても, 実験開始時から内側頸部の外側翼突筋付着 部骨縁に骨吸収を誌めたが，対照群では 9 週目には骨吸 収は停止していた。しかし，実験群では 9 週目以降で も，軽微ながら骨吸収像は継続していることを認めた。 このととは，鈴木（1971）201や樋田（1982２4) らが述べ たように，下㖽が不安定な状態となり，神経筋機構に不 調和などの異常が現われたためと著者は考える.しかし ながら，その程度は両側霜牙欠損の場合，片側雪牙欠損 状態の場合ほど強くないと言える。 


\section{結}

\section{論}

焧合異常が下䫇頭に及ぼす影響を知るため，ラットの 上顎左右全臼歯拔去（A群），および同拔去と上顎左右 切雪の定期的な削合を行ない (B 群), 実験的に咬合異 常を落起させ, 下蕦頭の変化を病理組織学的及び走查電 子顕微鏡的に検索し, 次のような結果を得た。

1. 実験 $\mathrm{A}$ 群, B 群とも対照群と同椂な体重増加傾向 を示した。

2. 実験 $\mathrm{A}$ 群の中央部より内側部にかけての embryonic zone に特異的な変化を早期より諗めた。

a . 光顕による観察で，実験後 1 週目より articular zone に接する部の細胞は丸みを帯び， 6 週目において embryonic zone 全体まで及んでいた. 以後, 細胞の配 列が不規則となり，軟举基質の増加が認められた。

b. SEM による観察で, 1 週目より articular zone よりの細胞は多数の突起を有し， 2 週目まで闰細胞の突 起は著明に発達し, 形態は丸みを帯びてくる. 以後, 細 胞の突起は減少し, 9 週目より基質の膠原原線維の走行 が一部不規則になっていた。

3. 実験B群の内側部の embryonic zone に実験A 群よりも大きな特異的な変化を早期より認めた。

a . 光顕に上る観察で，経週的に軟骨基質が増加し， 細胞の形態は丸みを带び, 配列は不規則となり，4週目 で最も著明となっていた，以後，細胞の配列はわずかに 規則的になるものの，形態はより丸みを帯び，transi- tional zone と区別できなくなっていた。

b. SEM に上る観察で，基質の膠原原線維の変化は 走行の乱れとして始まり, 小束化を来し， 4 週目で最も 著明となる. 以後，線維の走行は規則的になり緻密化を たどる。

4. 下顎頭軟骨層の菲薄化は hypertrophic zone で 著しく, 実験 $\mathrm{A}$ 群，B群ともに3日目ですでに菲薄とな っていたが，その後 3 週目までは逆に肥厚し， 4 週目よ り再度菲薄となっていた。

5. 下顎頭外側部では，実験 $\mathrm{A}$ 群，B群ともに大きな 変化は認められなかった。

6. 下顎頭内側頸部の外側翼哭筋付着部骨縁の骨吸収 は, 対照群では 9 週目でほぼ停止していたが, 実験群で は 9 週目でも軽微ながら，いぜん骨吸収像を認めた。

7. 下䫟頭の骨化は, 対照群, 実験 $\mathrm{A}$ 群, 実験 $\mathrm{B}$ 群の 順に進行していた。

以上より, 咬合異常の違いにより, 䫫関節異常にも差 異が生じることが示唆された。

稿を終わるに臨み, 終始, 御愁篤なる御指導と御校閲 を賜った恩師九州菌科大学第 1 口腔外科学教室山田長敬 教授に深甚の謝意を捧げます.

また、日敒をいとわず種々御教示,御指導を戴きました 刍山嘉光助教授に満腔の謝意を表し，あわせて本研究に 種々御協力戴きました教室員諸兄に御礼申し上げます.

\section{引用 文 献}

1) 上野 正：顎関節疾患の診断と治療.日歯評論 $170: 1-7,1957$.

2) 中村允也 : 䫁関節症の臨床的研究. 口病誌 $26: 986-1012,1959$.

3 ）岡達: 䄣関節症の研究一成因および臨休像を中心に一. 口科誌 $16: 116-123,1967$.

4 ）関 秀孝: 䪽関節症の補緅学的研究. 第 1 報, 靧関節症患者の咬合に関する研究. 口病誌 $35: 213-227$, 1968 .

5 ）中沢勝宏：顎関節症に㧈ける下顎運動の分析．歯科学報 $74: 277-311 ， 1974$.

6 ）中村公雄・山内哲義・榎阪 朗・下総高次：顎関節症患者の経時的観察ならびに咬合に関する研究. 補綴誌 $19: 217-231,1975$.

7) 中村公雄・山内哲義・榎阪 朗・下総高次：顎関節症患者の統計的観察. 補経誌 $19: 232-237,1975$.

8 ）三谷春保：咬合性蕦関節症の筋への影響. 日歯評論 $392: 48-55,1975$.

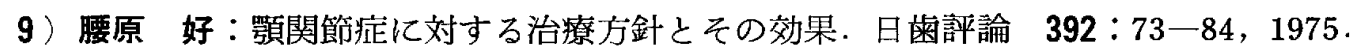

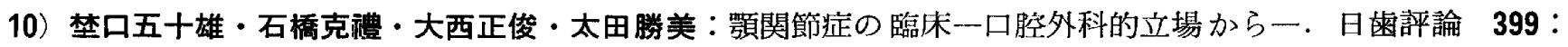
$68-78,1976$.

11）鬼塚謙治：頇関節症に関する臨床的研究. 九州菌会誌 $30 ： 662-708,1977$.

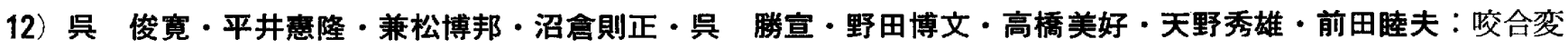




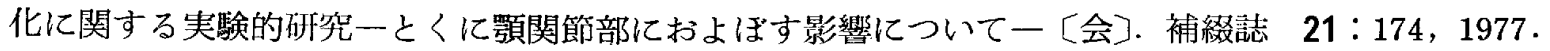

13）山䗁 博：片側咬合举上による両側領関節の変化に関する実験的研究. 九州歯会誌 $33: 257-280,1979$.

14）鬼塚啓史：咬合挙上冠除去後の顎関節への影響闺関する実験的研究. 九州霜会誌 $37: 340-359,1983$.

15) Avant, F.B., Averill, C.J. and Hahn, W.E. : Changes in the temporomandibular joint of rats caused by alternations in the intermaxillary relationship of the teeth. J. Dent. Res. $31: 499-500,1952$.

16) Cimasoni, G. : Histopathology of the temporomandibular joint following bilateral extraction of molars in the rat. Oral Surg. $16: 613-621,1963$.

17) Furstman, L. : The effect of loss of occlusion upon the mandibular joint. Am. J. Orthod. 51 : $245-261,1965$.

18）小野尊睦・石井保雄・三木 毅・松崎逸郎：ラット䫇関節の形態病学的研究. 第 2 報. 実験的片側㖫合に於 けるラット額関節部の変化について〔会〕. 日外誌 $13: 423,1967$.

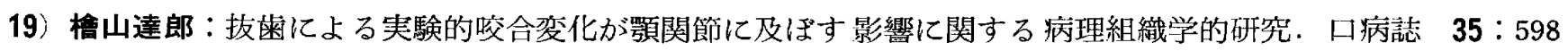
$-612 ; 1968$.

20）鈴木 禎：各種動物の顎関節円板にみられる軟栺紐胞の分布並びに機能的意義について３. 実験的咬合異 常によって生ずるラット顎関節部の変化, 特に㖽関節円板の変化について. 菌科学報 $71: 1337-1348$, 1971.

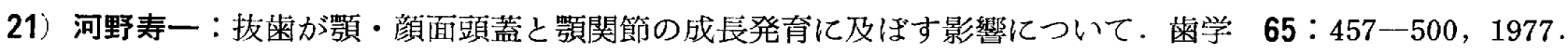

22）角野博俊：下顎頭損傷の修復に関する実験病理学的研究一ラット顎関節損傷の顎顔面発育に及ぼす影響を中 心にして一。口科誌 $32: 69-109,1983$.

23）喜久田利弘：片側柬牙久損によるサル顎関節の病理組織学的研究. 九州歯会誌 $34: 254-274,1980$.

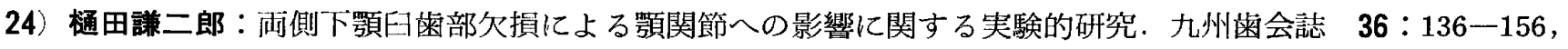
1982 .

25）塩田 覚・角野博俊・南 英治・小野尊睦：ラットに扔ける下䫓頭の走查電子顕微鏡的研究. 日口外誌 26 : $42^{--48, ~} 1980$.

26）田口 望：顎関節関節軟骨抢よび関節円板の微細構造に関する研究. 日口外誌 $26: 929-944,1980$.

27) Silbermann, M. and Frommer, J. : Ultrastructure of developing cartilage in the mandibular condyle of the mouse. Acta Anat. $90: 330-346,1974$.

28）塩田 覚・南 英治・角野博俊・小野尊睦：ラットの下䋶頭軟骨に関する電子顕微鏡的研究. 日口外誌 26 $: 628-636,1980$.

29）森田修一：ラット下額頭軟骨の生後発育に関する微細構造学的, 細胞化学的研究. 日矯歯誌 $41: 171-201$, 1982.

30）布施修一郎・野口五十雄：咬合異常における顎関節軟骨と関節円板の走查電子顕微鏡による実験的研究 [会]. 日口外誌 $22: 933,1976$.

31）布施修一郎・野口五十雄：咬合異常における買関節構成体の SEM による実験的研究. 第 2 報 経济的観 察〔会]. 日口外誌 $24: 1362,1978$.

32) Breitner, C. : Further investigations of bone changes resulting from experimental orthodontic treatment. Am. J. Orthod. $25: 605-632,1941$.

33) Furstman, L.L. : Normal age changes in the rat mandibular joint. J. Dent. Res. $45: 291-296$, 1966.

34）三木 毅：ラット㖽関節の発生並びに発育に関する研究. 京大口科紀要 $12 ： 1-30,1972$.

35）小嶋 昇：導電染色法による Rat 照骨骨端軟骨の走査電子顕微鏡による観察. 日大歯学 $55 ： 366-371$, 1981.

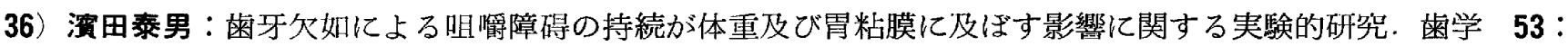


$284-301,1965$.

37) Folke, L.E.A. and Stallard, R.E. : Condylar adaptation to a change in intermaxillary relationship. J. Periodont. Res. $1: 79-89,1966$.

38）野口規久男：外力を与えた際の幼若ラット下顎頭の研究- ${ }^{3}$ H-thy midine オートラジオグラフィーによる 観察一。 口病誌 $37: 222-241,1970$.

39）今村正史：下顎を偏位させた際のラット下顎頭軟骨の反応. 口病誌 $40 ： 457-475,1973$.

40) Silbermann, M. and Frommer, J. : Vitality of chondrocytes in the mandibular condyle as revealed by collagen formation. An autoradiographic study with ${ }^{3} \mathrm{H}$-proline. Am. J.Anat. $135: 359-370,1972$.

41）岡田充泰：ラット下顎頭の発育に関する実験的研究-一皮下移栕した下顎頭の発育について一。阪大柬学誌 $22: 21-45,1977$.

42）深沢裕文：閉口運動に関与する筋群切除後のラット下額頭の成長発育に関する研究. 日矯柬誌 $39: 303$ 一 318,1980 . 